\title{
THERMAL EXPANSION OF INSULATING MATERIALS
}

\author{
By Wilmer H. Souder and Peter Hidnert
}

CONTENTS

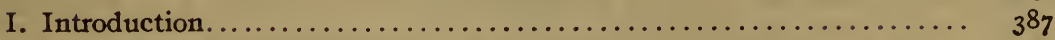

II. Previous work on porcelain. ............................ 388

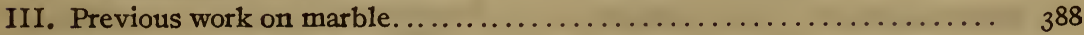

IV. Apparatus and specimens. .............................. 390

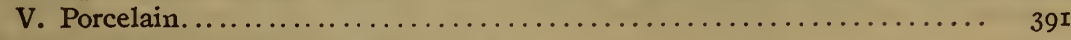

VI. Phenol condensation products, etc....................... 399

VII. Marble and limestone.................................. 4 II

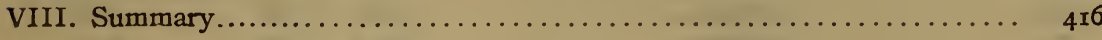

\section{INTRODUCTION}

The material here presented is selected from the mass of data accumulated-during thermal expansivity tests, and is of importance where insulating materials are subjected to temperature variations. The range of expansion coefficients is rather large, extending from a value of $1.6 \times 1 \mathrm{IO}^{-6}$ for certain porcelains to $109 \times 10^{-8}$ for a specimen of celluloid.

In addition to the wide range in coefficients it has also been found that practically all of the molded materials, such as bakelite, condensite, hard rubber, and celluloid, take up a permanent length change when carried through a temperature cycle, especially if temperatures above $60^{\circ} \mathrm{C}$ are reached. This length change, always a shrinkage, may work to advantage in cases where a slight shrinkage tends to compress and retain metallic electrodes or inserts. On the other hand, these changes become very serious in precision apparatus depending upon accurate dimensions.

The following materials have been investigated and are included in this report: Porcelain, bakelite, condensite, formica, celluloid, hard rubber, marble, and limestone. 


\section{PREVIOUS WORK ON PORCELAIN}

Some of the results of previous experimental determinations of the thermal expansion of porcelain are summarized in the following table. The values given for $a$ and $b$ are to be substituted in the general quadratic equation

$$
L_{\mathrm{t}}=L_{\mathrm{o}}\left(\mathrm{I}+a t+b t^{2}\right)
$$

where $L_{o}$ is the length of the material at $0^{\circ} \mathrm{C}$ and $L_{t}$ the length at $t^{\circ} \mathrm{C}$ within the proper temperature range.

TABLE 1

\begin{tabular}{|c|c|c|c|c|}
\hline \multirow{2}{*}{ Kind of porcelain } & \multirow{2}{*}{ Observer } & \multirow{2}{*}{$\begin{array}{c}\text { Temperature } \\
\text { range }\end{array}$} & \multicolumn{2}{|c|}{ Coefficients } \\
\hline & & & $a$ & $b$ \\
\hline & & ${ }^{\circ} \mathrm{C}$ & & \\
\hline Bayeux.................... & Tutton $a . . . . . . .$. & $0-120$ & $2.522 \times 10^{-6}$ & $7.43 \times 10^{-8}$ \\
\hline Do........ & Bedford........... & $0-600$ & 3.425 & 1.07 \\
\hline Do................ & Chappuis......... & $0-83$ & 2.824 & 6.17 \\
\hline Berlin....................... & Holborn and Day & $250-625$ & 2.954 & 1.125 \\
\hline
\end{tabular}

a Proc. Phys. Soc. of Lond., 18, p. 182; 190r-r903.

$b$ Ann. der Phys. und Chem., 2, p. 505; 1900.

Tutton agrees with Chappuis that the thermal expansion of Bayeux or Berlin porcelains can not be represented by a quadratic equation throughout a temperature range exceeding a very few hundred degrees.

Brundige ${ }^{1}$ is of the opinion that expansion effects cause the major part of insulator deterioration. However, he points out that there are other investigators who believe that practically all insulator deterioration is attributed to porosity.

\section{PREVIOUS WORK ON MARBLE}

Roiti's Physics (vol. I, sec. 399, Hungarian translation, p. 457), gives as the average coefficient of expansion for $\mathrm{I}^{\circ} \mathrm{C}$ between $\mathrm{o}^{\circ}$ and $100^{\circ} \mathrm{C}$, the following values:

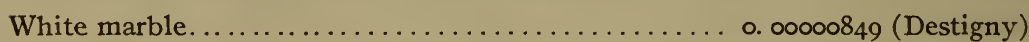

Do.................................. . 00001072 (Dunn and Sang)

Fröhlich ${ }^{2}$ found it necessary to know the coefficient of expansion of a large ring (standard of inductance) made from Carrara marble in order to determine the dimensions at a given temperature. From observations at room temperature and at $100^{\circ} \mathrm{C}$ (steam)

1 Trans. Amer. Inst. Elec. Eng., 36, p. 535; 1917.

3 Wiedemann Annalen der Physik und Chemie, 61, p. 206; 1907. 
on a $30 \mathrm{~cm}$ specimen cut from the same block of marble used for the ring, he obtained 0.000012 for the average coefficient of expansion between 15 and $100^{\circ} \mathrm{C}$. However, he does not state whether the specimen returned to its original dimensions after cooling.

Kaye and Laby (Physical and Chemical Constants, etc., I9I I) of the National Physical Laboratory give $1.4 \times 10^{-6}$ to $3.5 \times 10^{-8}$ for the coefficient of expansion of marble at $15^{\circ} \mathrm{C}$.

Grüneisen ${ }^{3}$ gives $4.3 \times 10^{-8}$ as the coefficient between $\mathrm{I} 4$ and $24^{\circ}$, and $10.5 \times 10^{-8}$ between 18 and $100^{\circ} \mathrm{C}$. After keeping a specimen at a constant temperature of $100^{\circ} \mathrm{C}$, he found the value $2.2 \times 10^{-6}$ for the coefficient of expansion between 14 and $24^{\circ} \mathrm{C}$.

Hallock ${ }^{4}$ determined the expansion of several marbles by comparing them with brass, and gives the following values from room temperature to $100^{\circ} \mathrm{C}$ :

A marble from Rutland, Vt................................. 00000659

A marble from Knoxville, Tenn........................... 00000495

A marble, "Keowa," from Georgia............................. $\begin{array}{r}525 \\ 50000348\end{array}$

$\begin{array}{rr} & 309\end{array}$

A marble, "Creole," from Georgia............................ 0000 I 10

A marble, "Cherokee," from Georgia............................ 00000740

855

The duplicate values are from different bars of the same marble.

He observed the phenomenon of permanent growth after heating, especially with the Vermont and Tennessee specimens. "Being heated for the first time to $100^{\circ} \mathrm{C}$ and allowed to cool, they did not contract to their original length, and the next two or three heatings resulted in continued but ever diminishing increments of length at ordinary temperatures; finally a permanent condition was reached." He also found that a Vermont marble when kept at constant temperature, contracted on drying and expanded on soaking in water.

In 1832 , W. H. C. Bartlett ${ }^{5}$ made determinations on the expansion of some stones at ordinary temperatures (range about $100^{\circ} \mathrm{F}$ ). He gives for the coefficient of expansion of marble, $0.000005668=$ $\frac{\mathrm{I}}{\mathrm{I} 76429}$ per degree Fahrenheit. He reached the conclusion that the fractures of the stones at Fort Adams, Newport Harbor, were due to ordinary changes of temperature. 
T. M. Reade ${ }^{6}$ also determined the expansion of several rocks, and gives as the coefficient of expansion of marbles the value $\frac{I}{I 84797}$ per degree Fahrenheit. (Temperature range not indicated.)

N. E. Wheeler ${ }^{7}$ investigated a specimen of white marble from Carrara, Italy. He obtained the following values for the coefficients of expansion per degree centigrade at intervals of $100^{\circ} \mathrm{C}$ :

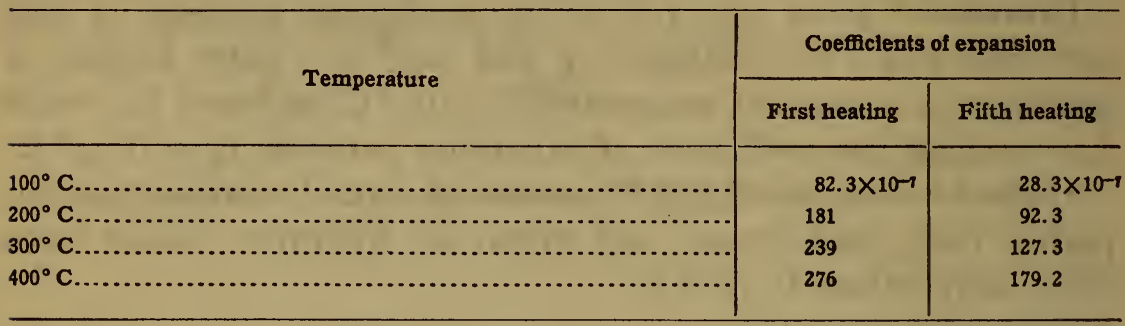

$\mathrm{Nisi}^{8}$ used an Abbe and Pulfrich interferometer over a range extending from $0^{\circ}$ to $40^{\circ} \mathrm{C}$. He found that the thermal expansion of white Carrara marble is different in different directions, and that the rate of expansion increases with temperature. He failed to obtain a marked permanent set, on account of his very limited temperature range. The coefficients of linear expansion for differently oriented specimens at temperatures between $0^{\circ}$ and $40^{\circ} \mathrm{C}$ varied from $-0.77 \times 10^{-6}$ to $+11.24 \times 10^{-6}$.

Nisi states that marble is by no means an homogeneous mass, and that the anomalous behavior of marble as regards thermal expansion is closely connected with the cleavage planes.

\section{APPARATUS AND SPECIMENS}

Each specimen was in the form of a straight rod or bar of uniform cross section. The length was about $30 \mathrm{~cm}$ and the cross section about $\mathrm{I} \mathrm{cm}$ square. Both ends were cylindrical in shape.

Two kinds of apparatus ${ }^{9}$ were used in making the thermal expansion tests-an oil bath ${ }^{10}$ and air furnaces.

In the furnaces the specimen was supported horizontally and a 2-mil platinum wire, which was previously annealed, hung

\footnotetext{
T The Origin of Mountain Ranges; 1886.

3 Trans. Royal Soc. of Canada, 3 d series, 4, p. x9; rgro-rx.

8 Tokyo Math.-Phys. Soc. Proc., ad series, 7, p. 97; 19 ${ }_{3}-14$.

9 This consists essentially of the apparatus designed and installed by A. W. Gray and L. W. Schad, formerly of this Bureau.

${ }^{10}$ For short description, see Preliminary Determination of the Thermal Expansion of Molybdenum, Scientific Papers, No. 332, p. 3r.
} 


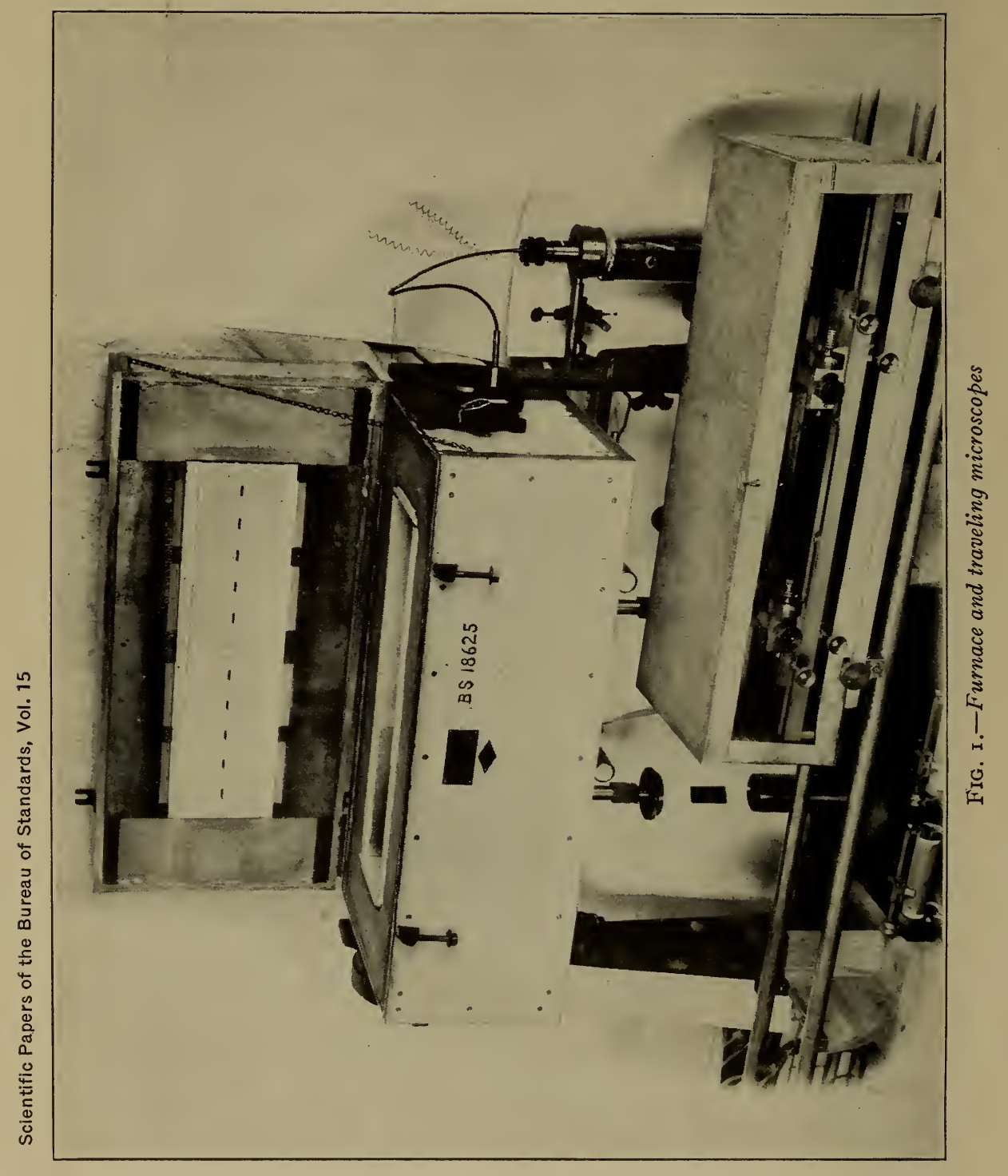


over each end. Each wire, hanging through a hollow tube below the end of the specimen and extending downward through and below the furnace, had at its lower end a vane (or weight) immersed in oil in order to dampen the vibrations. Heating was effected by electric resistance coils (outside, inside, and end coils). With careful manipulation it was possible to adjust the circuits so that during an observation the specimen was at a uniform temperature within one-tenth degree centigrade, from end to end.

The length changes were determined with a comparator consisting of two microscopes rigidly clamped on an invar bar at a distance from each other equal to the length of the specimen $(30 \mathrm{~cm}$.$) . The microscopes were so arranged that they could$ first be sighted on a standard-length bar kept at constant temperature, and then on the vertically suspended wires which were in contact with the ends of the specimen.

The apparatus shown in Fig. I was used for part of this research and portrays the essential method of making observations on materials. The furnace is shown with the top lifted. The traveling microscopes, which are sighted (simultaneously) on the two vertical wires hung from the specimen, are displaced to the right in order to show the construction of the tube protecting the vertical or drop wires. The left oil pot is removed to show the weight attached to the wire.

The temperatures in the oil bath and furnaces were determined by means of a copper-constantan and a platinum-platinum rhodium thermocouple, respectively.

\section{PORCELAIN}

Data on the thermal expansion of 40 samples of various kinds of porcelain are presented in this paper.

The coefficients of expansion of these materials vary over a wide range, as may be seen from the accompanying curves and the following table. It is remarkable that the various kinds of porcelain, when heated to high temperatures and then cooled to room temperature, returned to their approximate initial lengths, as is evident from the last column in the table; that is, there is no marked set or permanent change in dimension due to the heat treatment.

The expansion curves of porcelain may be divided into three classes: Straight-line, concave, and convex curves. In the straight-line curve, the rate of expansion is constant. (See $\mathrm{S}_{494}$ 
in Table 2.) The concave expansion curve shows that the rate of expansion increases with temperature, but the convex curve indicates that the rate of expansion decreases with temperature. Examples of concave curves are shown by $\mathrm{S}_{472}, \mathrm{~S}_{476}, \mathrm{~S}_{496}$, and $\mathrm{S}_{500}$; and examples of convex curves by $\mathrm{S}_{436} 6, \mathrm{~S} 480$, and $\mathrm{S}_{501}$.

TABLE 2

\begin{tabular}{|c|c|c|c|c|c|c|c|c|c|c|c|c|}
\hline \multirow{2}{*}{$\begin{array}{c}\text { Bu- } \\
\text { reaus } \\
\text { of } \\
\text { Stand- } \\
\text { ards } \\
\text { No. }\end{array}$} & \multicolumn{7}{|c|}{ Composition. } & \multicolumn{4}{|c|}{ Average coefficients $\times 10^{6}$} & \multirow{2}{*}{$\begin{array}{l}\text { Change } \\
\text { in } \\
\text { length } \\
\text { after } \\
\text { test } \\
\text { (per } \\
\text { cent) }\end{array}$} \\
\hline & $\begin{array}{l}\text { Per } \\
\text { cent } \\
\text { clay }\end{array}$ & $\begin{array}{l}\text { Per } \\
\text { cent } \\
\text { feld- } \\
\text { spar }\end{array}$ & $\begin{array}{l}\text { Per } \\
\text { cent } \\
\text { flint }\end{array}$ & $\begin{array}{l}\text { Per } \\
\text { cent } \\
\text { whit- } \\
\text { ing }\end{array}$ & $\begin{array}{c}\text { Per } \\
\text { cent } \\
\text { cal- } \\
\text { cine } \\
\text { No. } 14 e\end{array}$ & $\begin{array}{c}\text { Per } \\
\text { cent } \\
\text { silli- } \\
\text { manite } e\end{array}$ & $\begin{array}{c}\text { Per } \\
\text { cent } \\
\mathrm{Al}_{2} \mathrm{O}_{3}\end{array}$ & $\begin{array}{l}\text { Room } \\
\text { tem- } \\
\text { pera- } \\
\text { ture } \\
\text { to } \\
200^{\circ} \mathrm{C}\end{array}$ & $\begin{array}{l}200 \text { to } \\
400^{\circ} \mathrm{C}\end{array}$ & $\begin{array}{l}400 \text { to } \\
540^{\circ} \mathrm{C}\end{array}$ & $\begin{array}{l}400 \text { to } \\
600^{\circ} \mathrm{C}\end{array}$ & \\
\hline S391 & & & & & & & & 4.4 & 5.4 & & 5.8 & 0.00 \\
\hline S392 & & & & & & & & 4.6 & 5.4 & & 6.0 & .00 \\
\hline S393 & & & & & & & & 3.7 & 5.0 & & 5.4 & +.01 \\
\hline S399 & & & & & & & & 5.8 & 4.7 & ..... & 7.8 & +.01 \\
\hline$S 400$ & & & 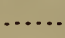 & & & & & 5.2 & 5.6 & 6.8 & & +.02 \\
\hline S401 & & & & & & & & 4.8 & 5.9 & 8.8 & $\cdots$ & +.04 \\
\hline S402 & & & & & & & & 4.3 & 6.1 & (........ & 7.9 & +.01 \\
\hline S405 & & & & & & & & 2.9 & 3.7 & (........ & 3.8 & -.01 \\
\hline S416 & & & $\cdots$ & & & & & 5.2 & 4.4 & $\ldots .$. & 4.9 & .00 \\
\hline S417 & .... & & $\cdots$ & & & & & 5.3 & 4.4 & ...... & 4.8 & +.01 \\
\hline $\mathrm{S} 436 a$ & 50 & & 20 & & $\ldots$ & & & 19.4 & 9.4 & 5.5 & & -.02 \\
\hline S437 & 50 & & 30 & & 20 & & & 19.6 & 11.1 & 8.1 & & +.03 \\
\hline $\mathbf{S} 438$ & 50 & & 20 & & 30 & & & 10.4 & 5.4 & 4.5 & & -.01 \\
\hline $\mathbf{S} 442 b$ & 50 & & 30 & & & & & 7.3 & 6.1 & 4.7 & & .00 \\
\hline $\mathrm{S} 443 c$ & 50 & & 20 & & .... & & & 8.9 & 4.4 & 4.1 & & .00 \\
\hline S 444 & 50 & & 20 & & 30 & & & 10.8 & 5.5 & 4.4 & & .00 \\
\hline S445 & 40 & & $\ldots$ & & 20 & 40 & & 3.4 & 4.2 & 4.8 & & .00 \\
\hline$S 472 d$ & 50 & $\cdots$ & 15 & & & & & 1.6 & 3.0 & 3.6 & & -.01 \\
\hline S476 & & & .... & & & & & 5.7 & 6.7 & 8.4 & & .00 \\
\hline S477 & .... & & $\cdots$ & & .... & & & 5.8 & 6.8 & 8.8 & & .00 \\
\hline S478 & 48 & & $\ldots$ & & 18 & 34 & & 10.4 & 5.6 & 4.4 & & -.01 \\
\hline S479 & 40 & & $\cdots$ & & 16 & 44 & & 10.9 & 6.6 & 7.8 & & +.06 \\
\hline S480 & 45 & . & ..... & 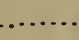 & 15 & 40 & & 8.9 & 5.0 & 5.1 & & -.01 \\
\hline S485 & 71.5 & 15.6 & 2.4 & 1.4 & & & 9.1 & 2.9 & 4.0 & & & -.02 \\
\hline S486 & 50 & 16 & 32.5 & 1.5 & & & & 6.2 & 4.6 & & & .00 \\
\hline S487 & 77 & 12.5 & ...... & 1.45 & & & 9.05 & 3.4 & 3.9 & & & -.01 \\
\hline S488 & 80.1 & 9.5 & ...... & 1.43 & & & 8. 97 & 3.1 & 3.8 & & & -.01 \\
\hline S489 & 85 & 13.5 & ....... & 1.5 & & & & 3.2 & 3.5 & & & -.01 \\
\hline S490 & 80 & 18.5 & ....... & 1.5 & & & & 2.9 & 4.0 & & & -.01 \\
\hline S491 & 80 & 13.5 & 5 & 1.5 & & & & 3.3 & 3.2 & & & -.01 \\
\hline S492 & 75 & 23.5 & $\ldots . .$. & 1.5 & & & & 3.5 & 4.5 & & & +.01 \\
\hline S493 & 75 & 18.5 & 5 & 1.5 & & & & 3.2 & 3.7 & & & -.01 \\
\hline S494 & 75 & 10 & 13.5 & 1.5 & & & & 4.1 & 4.1 & & & -.01 \\
\hline S495 & 70 & 23.5 & 5 & 1.5 & & & & 3.7 & ..... & & $\ldots . .$. & -.09 \\
\hline S496 & 70 & 19 & 9.5 & 1.5 & & & & 3.3 & 4.0 & & & .00 \\
\hline S497 & 70 & 15 & 13.5 & 1.5 & & & & 3.4 & 3.6 & & & .00 \\
\hline S499 & 80 & 10 & 8.5 & 1.5 & & & & 4.7 & 4.6 & & & .00 \\
\hline S500 & 75 & 13.5 & 10 & 1.5 & & & & 3.7 & 4.3 & & & -.01 \\
\hline S501 & 70 & 10 & 18.5 & 1.5 & & & & 6.1 & 5.1 & & 4.5 & -.02 \\
\hline S502 & 50 & 16 & 34 & & & & & 4.7 & 4.6 & & & .00 \\
\hline
\end{tabular}




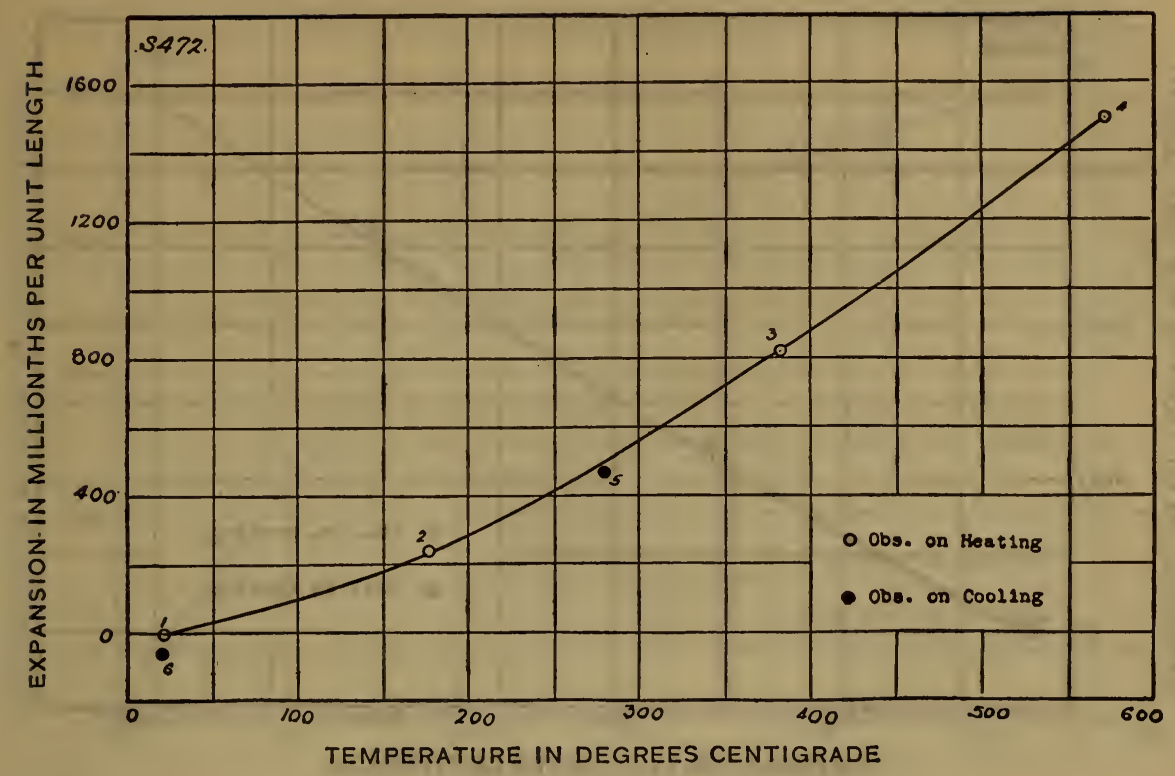

FIG. 2.-Expansion of porcelain $\left(S_{472}\right)$

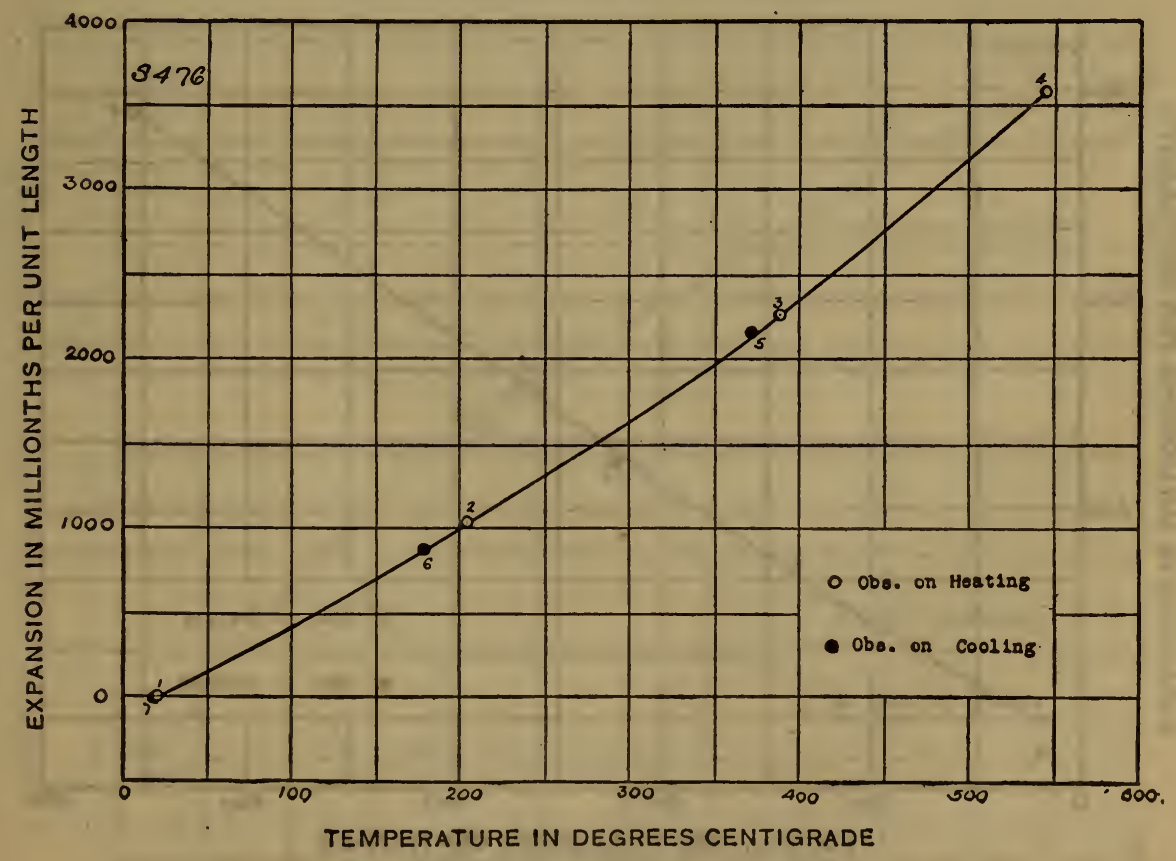

FIG. 3.-Expansion of porcelain $\left(S_{476}\right)$

$133855^{\circ}-19-2$ 


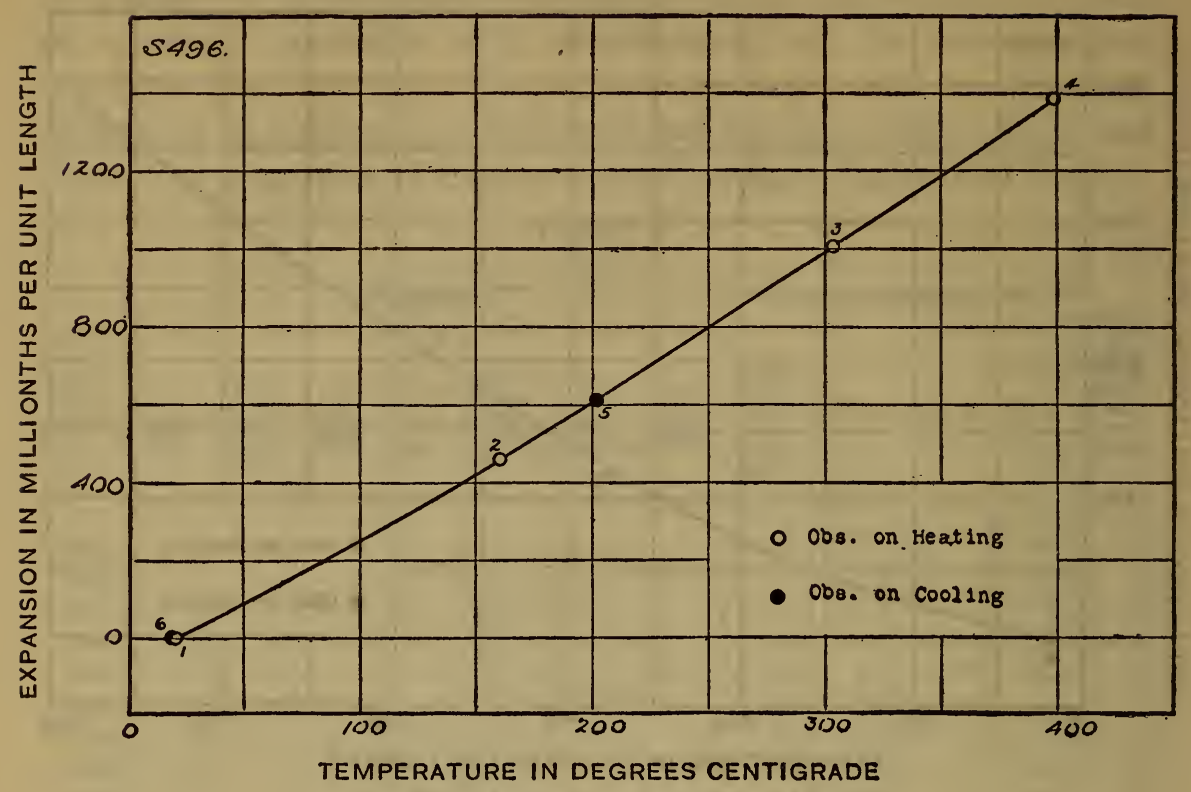

FIG. 4.-Expansion of porcelain (S 490$)$

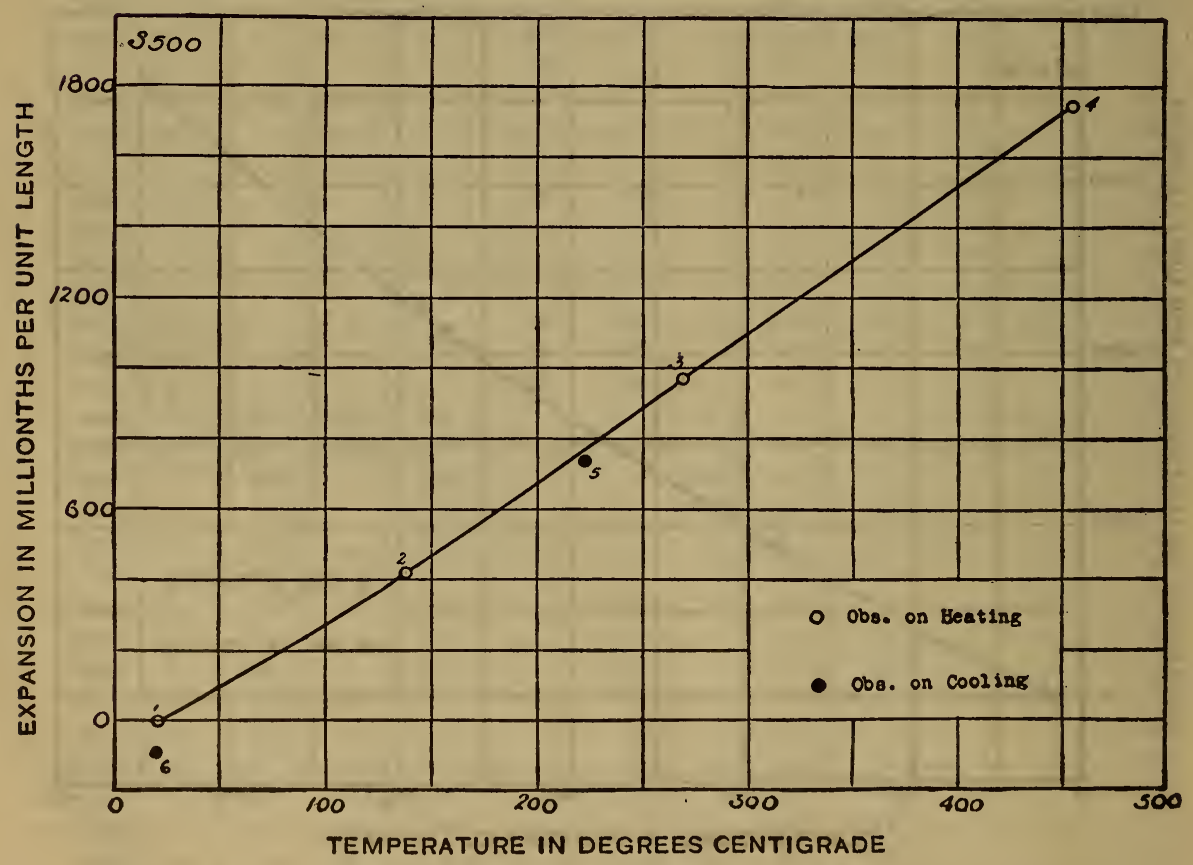

Fig. 5.-Expansion of porcelain ( $S$ 500) 


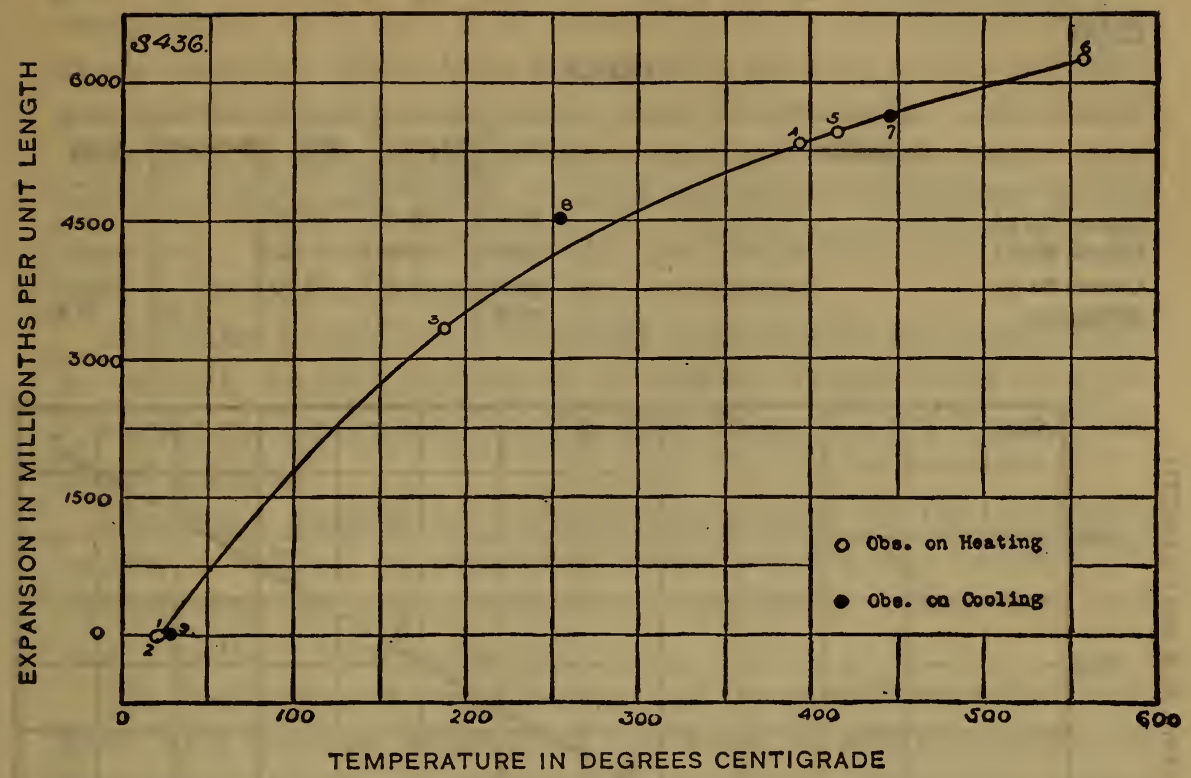

Fig. 6.-Expansion of porcelain $\left(S_{43}\right.$ )

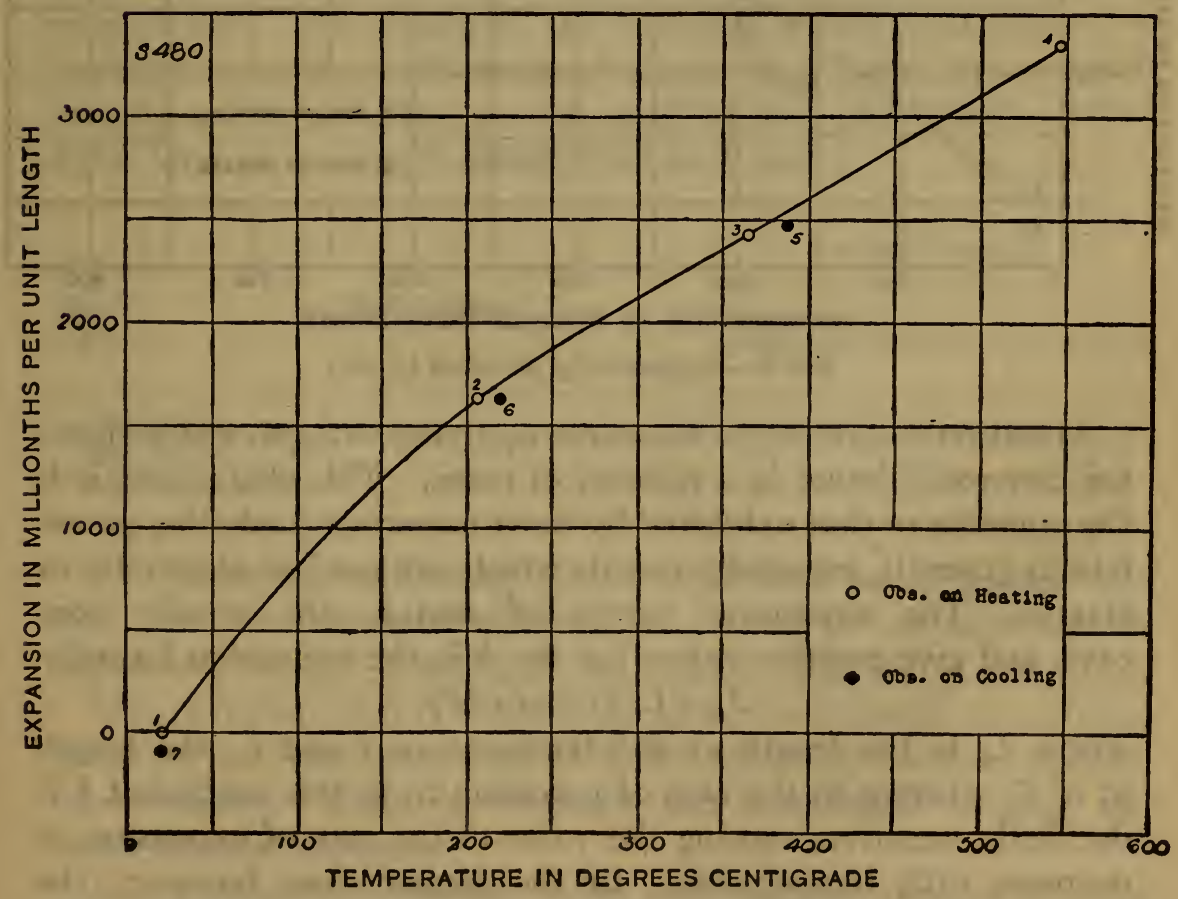

FIG. 7.-Expansion of porcelain ( $\left.S_{480}\right)$ 
The constituents of the calcines are given in the accompanying table.

\section{TABLE 3}

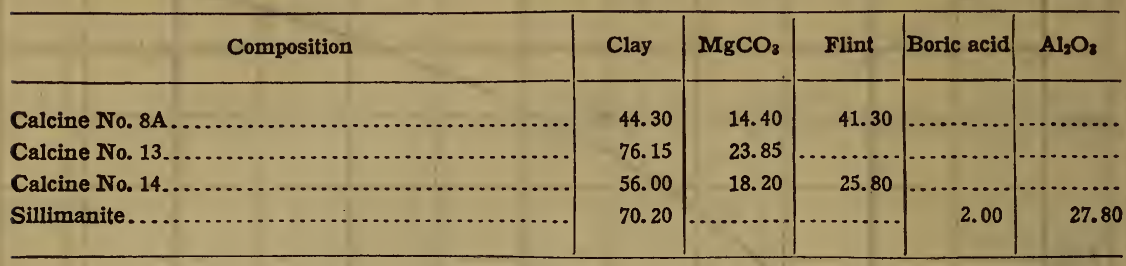

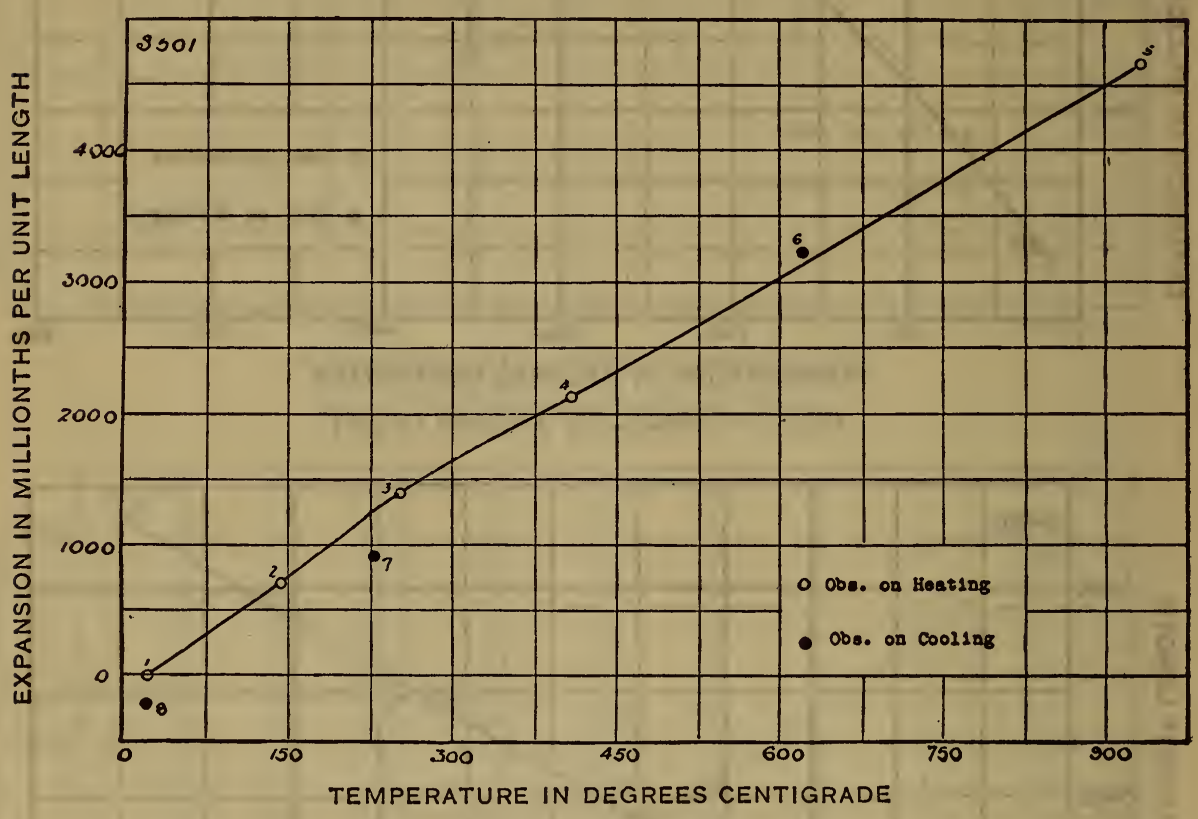

FIG. 8.-Expansion of porcelain (S 5OI)

Attention is directed to the curve applying to $\mathrm{S} 436$, which shows the convexity found in a number of cases. This characteristic is the opposite to that exhibited by most materials (including porcelain in general), especially metals which are used as electrodes or clamps. The expansion curves of metals are usually concave, and give positive values for the $b$ in the expansion formula:

$$
L_{t}=L_{o}\left(\mathrm{I}+a t+b t^{2}\right)
$$

where $L_{\mathrm{t}}$ is the length at any temperature $t$ and $L_{\mathrm{o}}$ the length at $0^{\circ} \mathrm{C}$, whereas in the case of porcelain $\mathrm{S}_{43} 6$ this coefficient $b$ is decidedly negative, causing the value of the rate of expansion to decrease with temperature. In the former case, however, the instantaneous coefficient or rate of expansion increases with temperature. 
The fact that the average coefficient of $\mathrm{S} 436$ between room temperature and $550^{\circ} \mathrm{C}$ is about the same as that of certain steels does not mean that these steels may be used as perfect matches for expansion (in spark plugs, for example). The rate of expansion of this porcelain decreases rapidly with temperature (see curve $\mathrm{S}_{43} 6$ and Table 2), while the rate of expansion of steel increases. Serious cracking of the porcelain may occur when the differential expansion approaches a maximum.

Porcelains having low coefficients of expansion have been found to exhibit marked resistance to sudden temperature changes. Plunging cold specimens into the blast flame did not cause checking or cracking.

The large number of varying constituents in the porcelains makes it difficult to obtain an exact relationship between the composition and the coefficients of expansion. However, some relations have been deduced.

The coefficients of porcelains having the same amounts of clay, flint, and calcines depend on the kind of calcines contained. Porcelains containing calcines No. $8 \mathrm{~A}$, No. 14 , and No. 13 have relatively large, intermediate, and small coefficients of expansion, respectively. For example, the following comparison shows the variations in the coefficients of $\mathrm{S}_{43} 6, \mathrm{~S}_{43} 8$, and $\mathrm{S}_{443}$, which contain 50 per cent clay, 20 per cent flint, and 30 per cent calcine. (The kind of calcine is different in each case.)

\begin{tabular}{|c|c|c|c|c|}
\hline \multirow{2}{*}{$\begin{array}{l}\text { Bureau } \\
\text { of } \\
\text { Stand- } \\
\text { ardds } \\
\text { No. }\end{array}$} & \multirow{2}{*}{ Ktod of calcine } & \multicolumn{3}{|c|}{ Average coefficients } \\
\hline & & $\begin{array}{l}\text { Room tem- } \\
\text { perature to } \\
200^{\circ} \mathrm{C}\end{array}$ & 200 to $400^{\circ} \mathrm{C}$ & 400 to $540^{\circ} \mathrm{C}$ \\
\hline $\begin{array}{l}\mathrm{S} 436 \\
\mathrm{~S} 438\end{array}$ & $\begin{array}{l}\text { No. } 8 \text { A.... } \\
\text { No. } 14 \ldots . .\end{array}$ & $\begin{array}{l}19.4 \times 10^{-8} \\
10.4\end{array}$ & $9.4 \times 10^{-6}$ & $5.5 \times 10^{-6}$ \\
\hline $\begin{array}{l}S 438 \\
\mathrm{~S} 443\end{array}$ & No. $13 \ldots \ldots \ldots$ & $\begin{array}{r}10.4 \\
8.9\end{array}$ & $\begin{array}{l}5.4 \\
4.4\end{array}$ & $\begin{array}{l}4.5 \\
4.1\end{array}$ \\
\hline
\end{tabular}

All porcelains containing 50 per cent clay, 20 or 30 per cent flint, and the remainder calcine (No. $8 \mathrm{~A}, \mathrm{I}_{3}$, or $\mathrm{I}_{4}$ ) have convex expansion curves. (See $\mathrm{S}_{436}, \mathrm{~S}_{437}, \mathrm{~S}_{438}, \mathrm{~S}_{442}, \mathrm{~S}_{443}$, and $\mathrm{S}_{444 .)}$

The porcelain ( $\mathrm{S}_{472}$ ) containing 35 per cent beryl, in addition to 50 per cent clay and i 5 peir cent flint, gave the lowest coefficient of expansion. Beryl is probably the constituent causing the small thermal expansion.

In a porcelain containing 40 per cent clay, an increase of 4 per cent in sillimanite and a corresponding decrease in calcine No. I4, 
caused a marked increase in the coefficients, as shown by the following values:

\begin{tabular}{|c|c|c|c|c|c|}
\hline \multirow[b]{2}{*}{ Bureau of Standards No. } & \multirow{2}{*}{$\begin{array}{l}\text { Sillimanite, } \\
\text { per cent }\end{array}$} & \multirow{2}{*}{$\begin{array}{c}\text { Calcine } \\
\text { No. } 14, \text { per } \\
\text { cent }\end{array}$} & \multicolumn{3}{|c|}{ Average coefficients } \\
\hline & & & $\begin{array}{l}\text { Room tem- } \\
\text { perature to } \\
200^{\circ} \mathrm{C}\end{array}$ & 200 to $400^{\circ} \mathrm{C}$ & 400 to $540^{\circ} \mathrm{C}$ \\
\hline S445.... & 40 & 20 & $3.4 \times 10^{-6}$ & $4.2 \times 10^{-6}$ & $4.8 \times 10^{-6}$ \\
\hline S479........... & 44 & 16 & 10.9 & 6.6 & 7.8 \\
\hline
\end{tabular}

In a porcelain containing 40 per cent sillimanite, an increase of 5 per cent in clay and a corresponding decrease in calcine No. 14 , caused an increase in the coefficients, as shown by the following values:

\begin{tabular}{|c|c|c|c|c|c|}
\hline \multirow[b]{2}{*}{ Bureau of Standards No. } & \multirow{2}{*}{$\begin{array}{c}\text { Clay, per } \\
\text { cent }\end{array}$} & \multirow{2}{*}{$\begin{array}{c}\text { Calcine } \\
\text { No. 14, per } \\
\text { cent }\end{array}$} & \multicolumn{3}{|c|}{ Average coefficients } \\
\hline & & & $\begin{array}{l}\text { Room tem- } \\
\text { perature to } \\
200^{\circ} \mathrm{C}\end{array}$ & 200 to $400^{\circ} \mathrm{C}$ & 400 to $540^{\circ} \mathrm{C}$ \\
\hline S445.. & 40 & 20 & $3.4 \times 10^{-6}$ & $4.2 \times 10^{-6}$ & $4.8 \times 10^{-6}$ \\
\hline S480.. & 45 & 15 & 8.9 & 5.0 & 5.1 \\
\hline
\end{tabular}

Three specimens, $\mathrm{S}_{4} 85, \mathrm{~S}_{487}$, and $\mathrm{S}_{4} 88$, containing from 71.5 to $80 . \mathrm{I}$ per cent clay and about 9 per cent $\mathrm{Al}_{2} \mathrm{O}_{3}$ had low coefficients of expansion (2.9 to $3.4 \times 10-{ }^{\circ}$ between room temperature and $200^{\circ} \mathrm{C}$, and 3.8 to $4.0 \times 10-^{6}$ between 200 and $400^{\circ} \mathrm{C}$ ).

The porcelains, $\mathrm{S}_{4} 89$ to $\mathrm{S}_{50} \mathrm{Or}$, inclusive, containing from 70 to 85 per cent clay, in addition to feldspar (Io to 23.5 per cent), flint (o to 18.5 per cent), and Whiting ( $\mathrm{r} .5$ per cent), have low coefficients of expansion, which vary from 2.9 to $6.1 \times 10-{ }^{6}$ and from 3.2 to $5.1 \times 1 \mathrm{IO}^{\circ}$ for the ranges extending from room temperature to $200^{\circ} \mathrm{C}$ and from $200^{\circ}$ to $400^{\circ} \mathrm{C}$, respectively.

Most of the porcelains described above are products of this Bureau's Pittsburgh laboratory, from which additional information ${ }^{11}$ relating to composition, baking, etc., may be secured. 
VI. PHENOL CONDENSATION PRODUCTS, ETC.

An extended study was made of these materials with a view to determining their applicability for use in instruments of high precision which may be subjected to temperature variations.

The accompanying representative figures are self-explanatory, and in general show the tendency of contraction at constant tem-

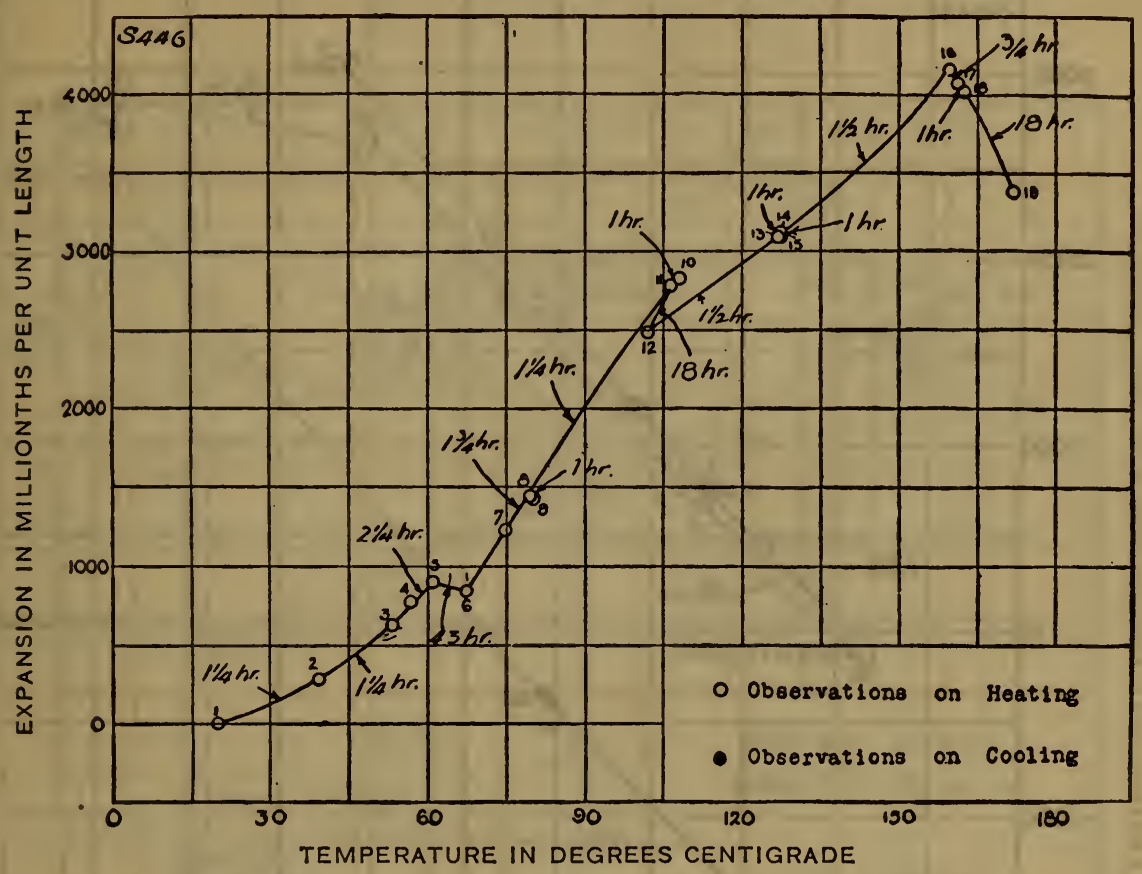

FIG. 9.-Expansion of bakelite-dilecto (black) $S 446$

perature (above $60^{\circ} \mathrm{C}$ ). In most cases, after cooling to room temperature, these materials show a marked diminution in length. The numbers near the circles represent the order of the observations. The time elapsing between consecutive observations is indicated. When the time is less than one hour (except at critical temperatures) it is not indicated. 


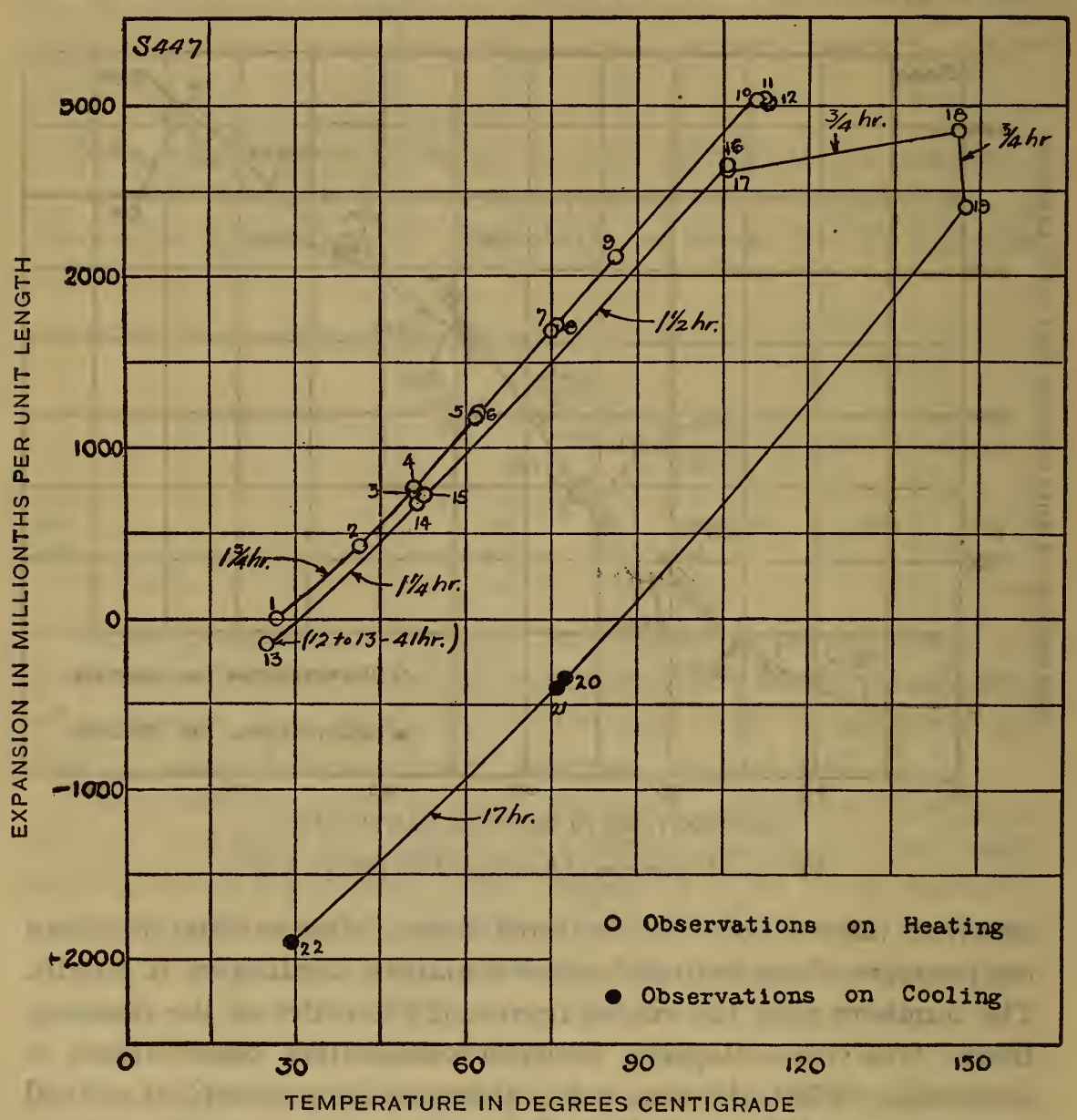

FIG. I0.-Expansion of bakelite-dilecto (black) $S 447$ 


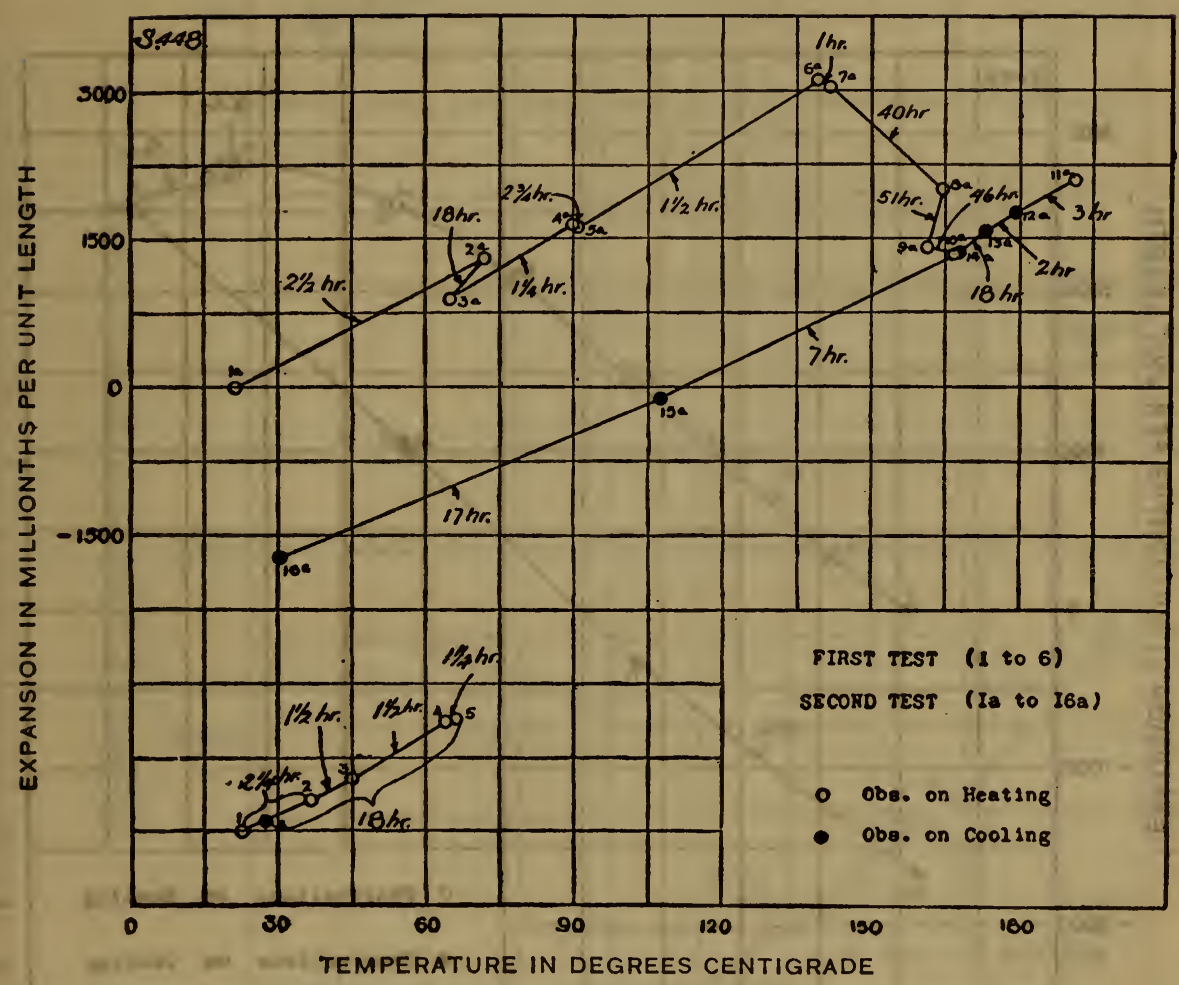

FIG: Ix.-Expansion of bakelite-dilecto (natural $X X$ grade) $S 448$ $133855^{\circ}-19-3$ 


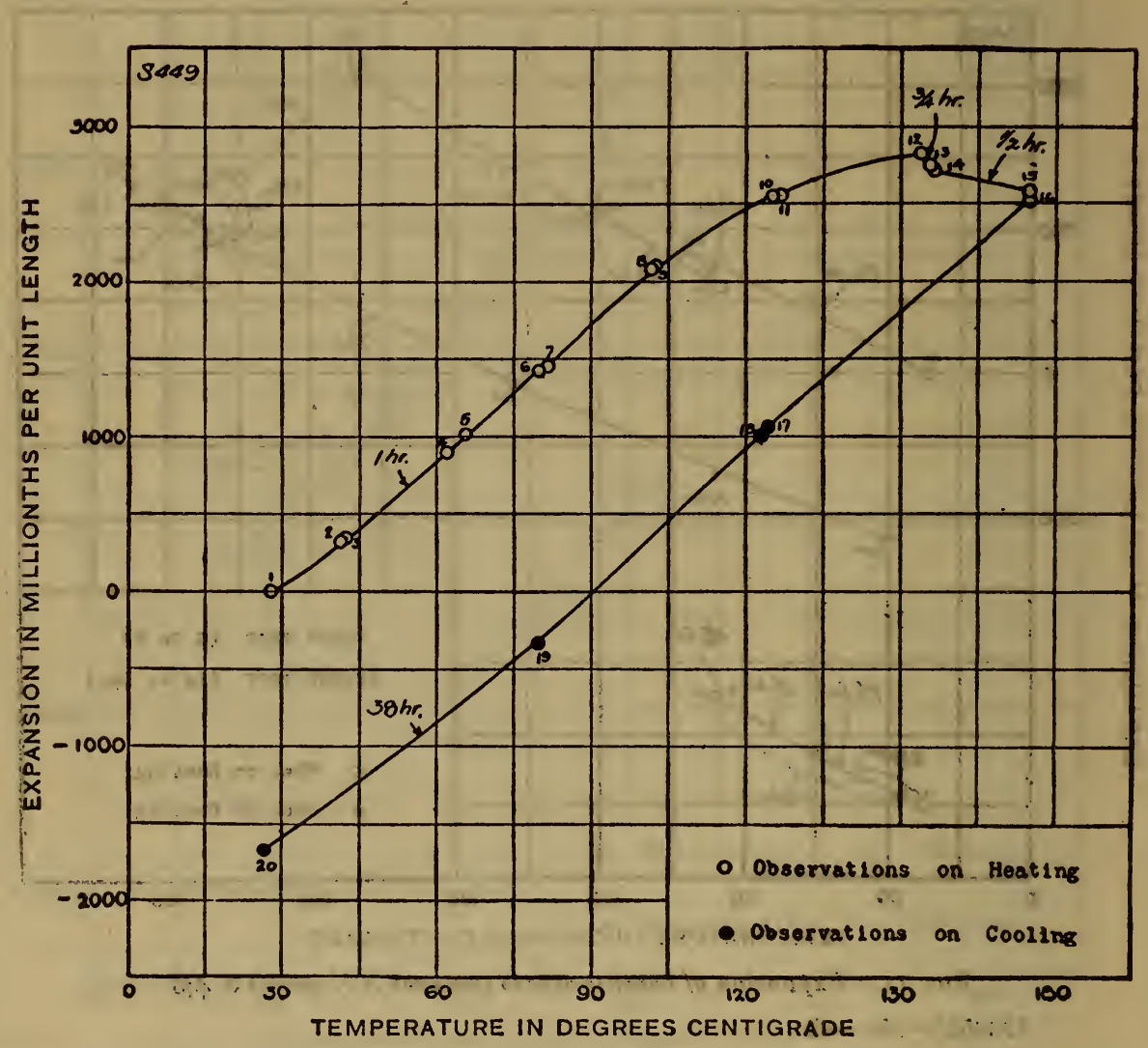

FIG. 12.-Expansion of bakelite-dilecto (natural XX grade) $S 449$ 


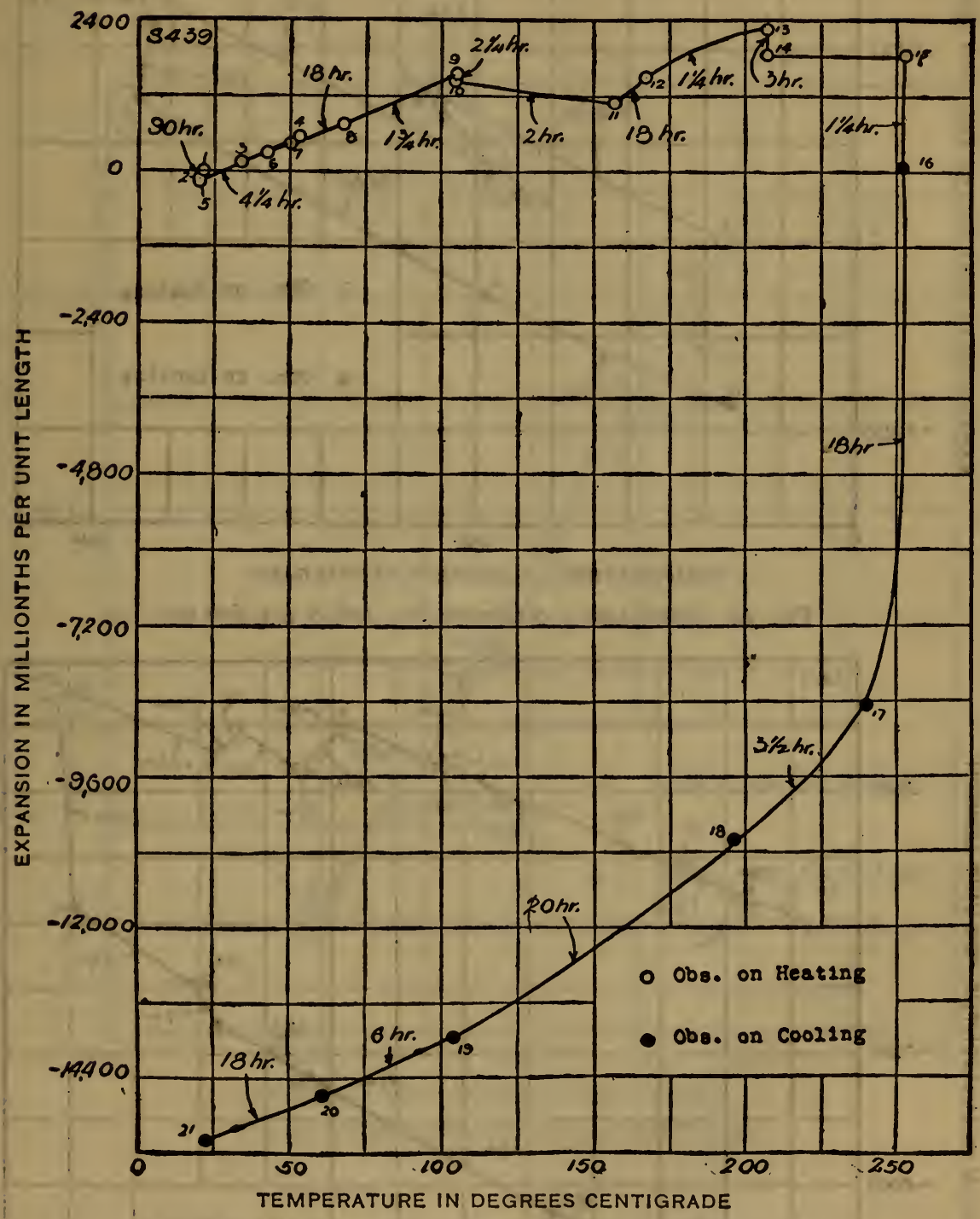

Frg. 13.-Expansion of bakelite-dilecto ( $X X$ grade) $S 439$ 


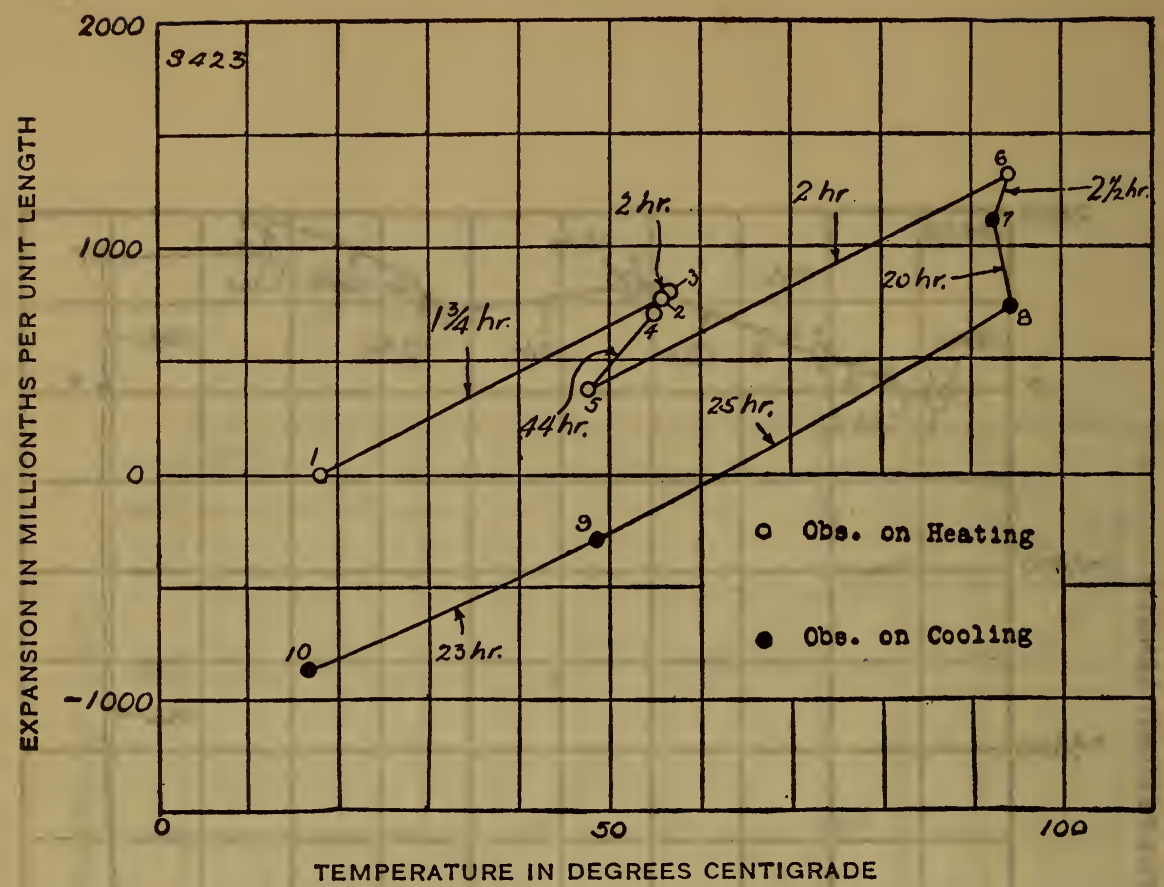

FiG. 14.-Expansion of condensite (No. 128) $S 423$, first test

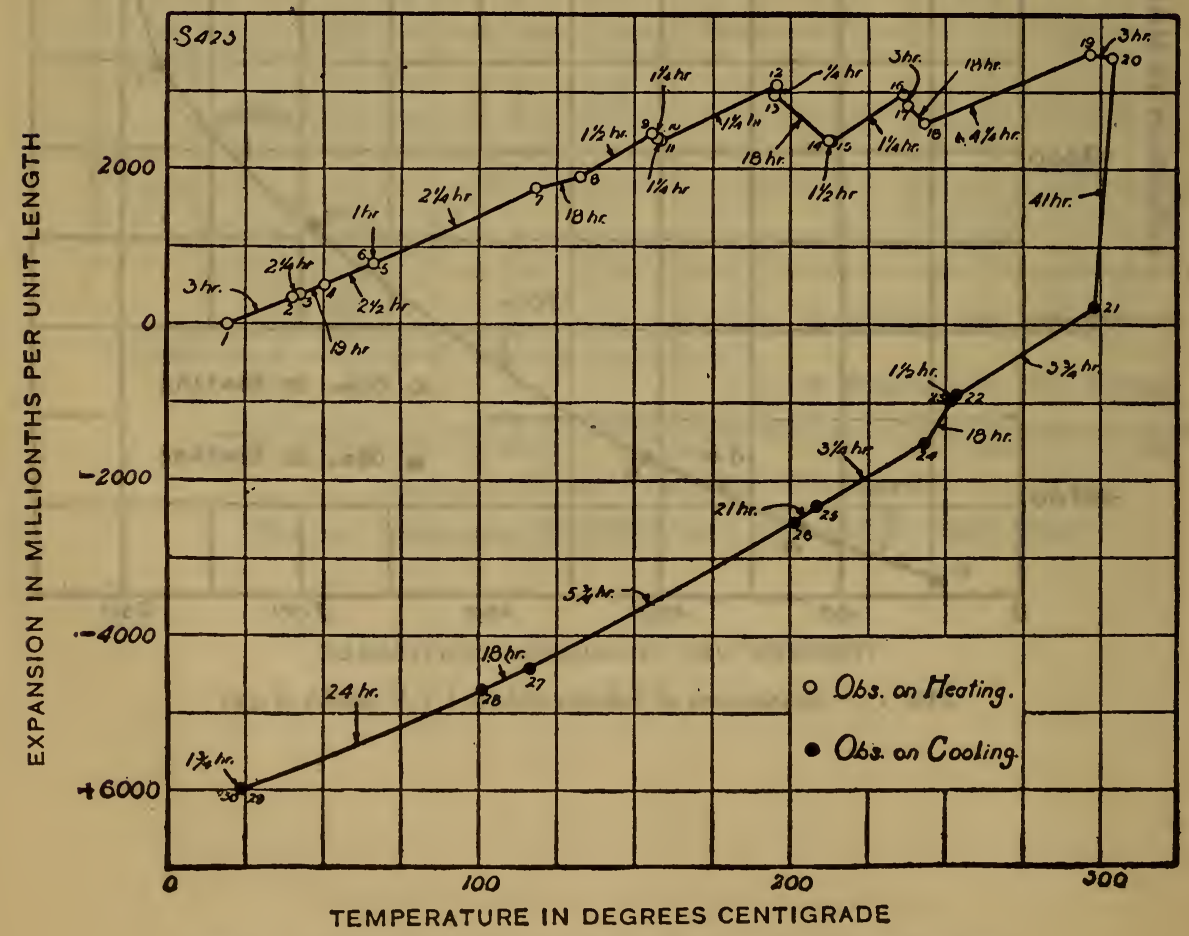

Frg. 15.-Expansion of condensite (No. 128) $S$ 423, second test 


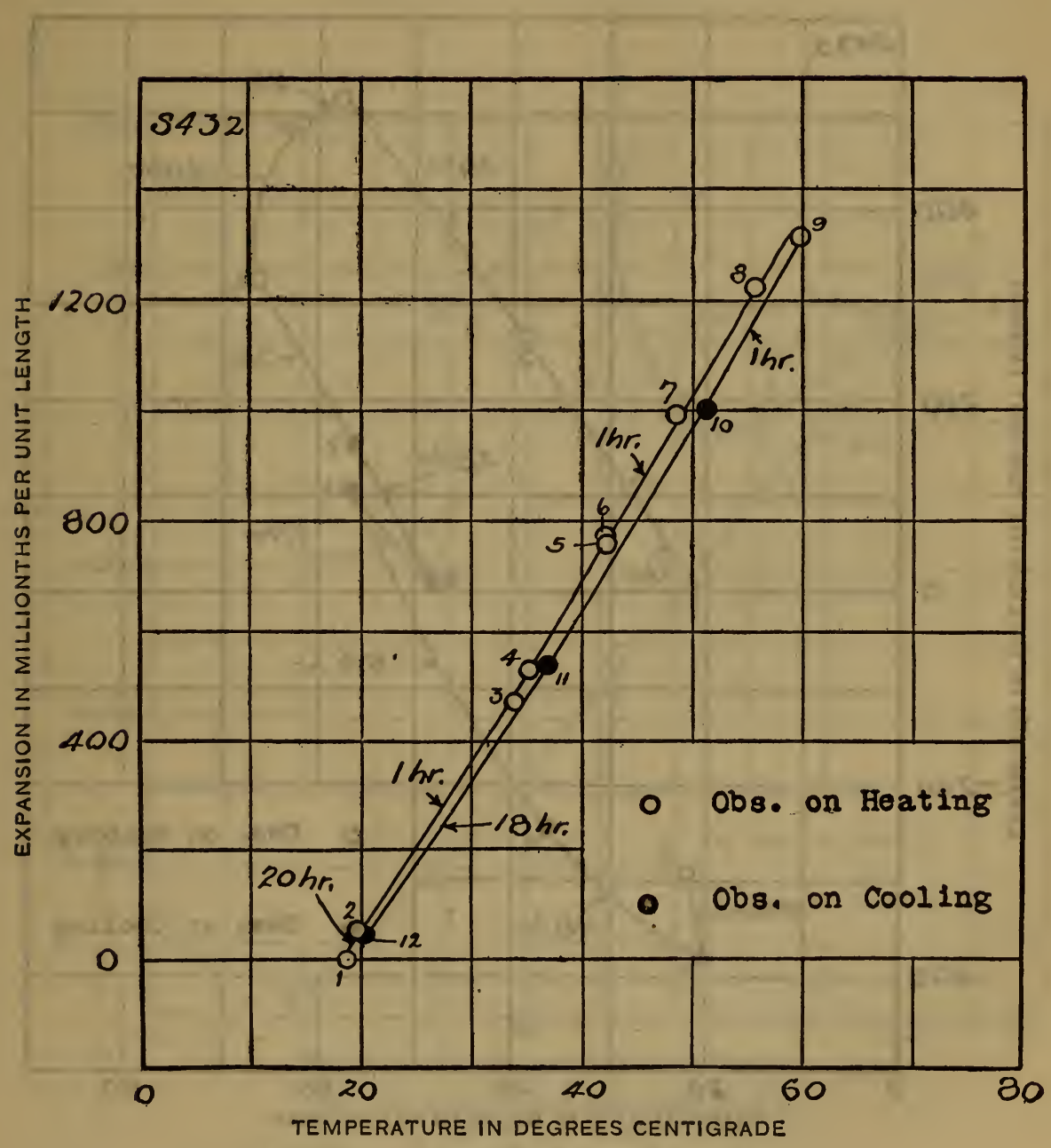

FIG. I6.-Expansion of formica (grade M) $S 432$ 


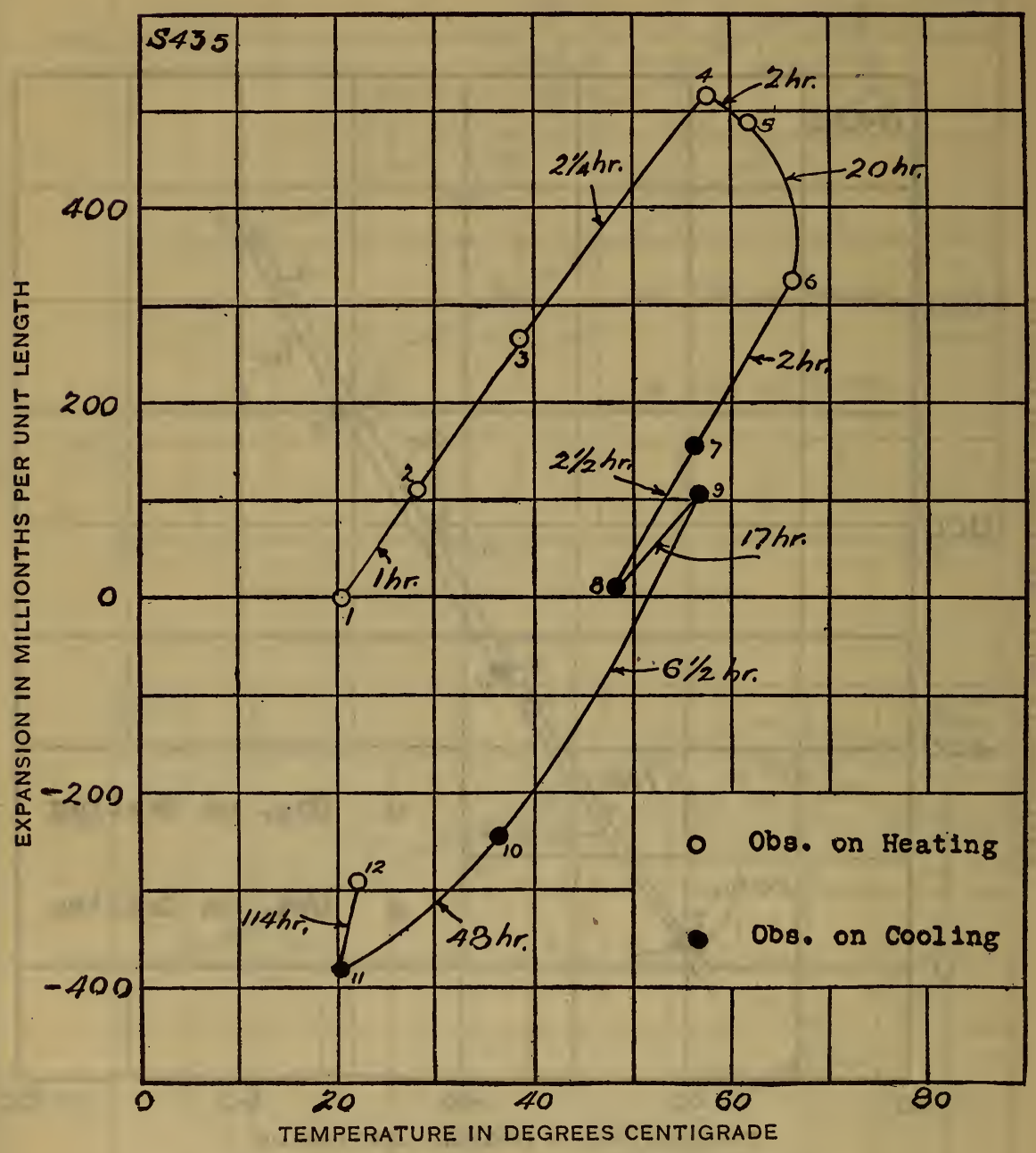

FIG. $x$ 7.-Expansion of formica (grade $M$ ) $S 435$ 


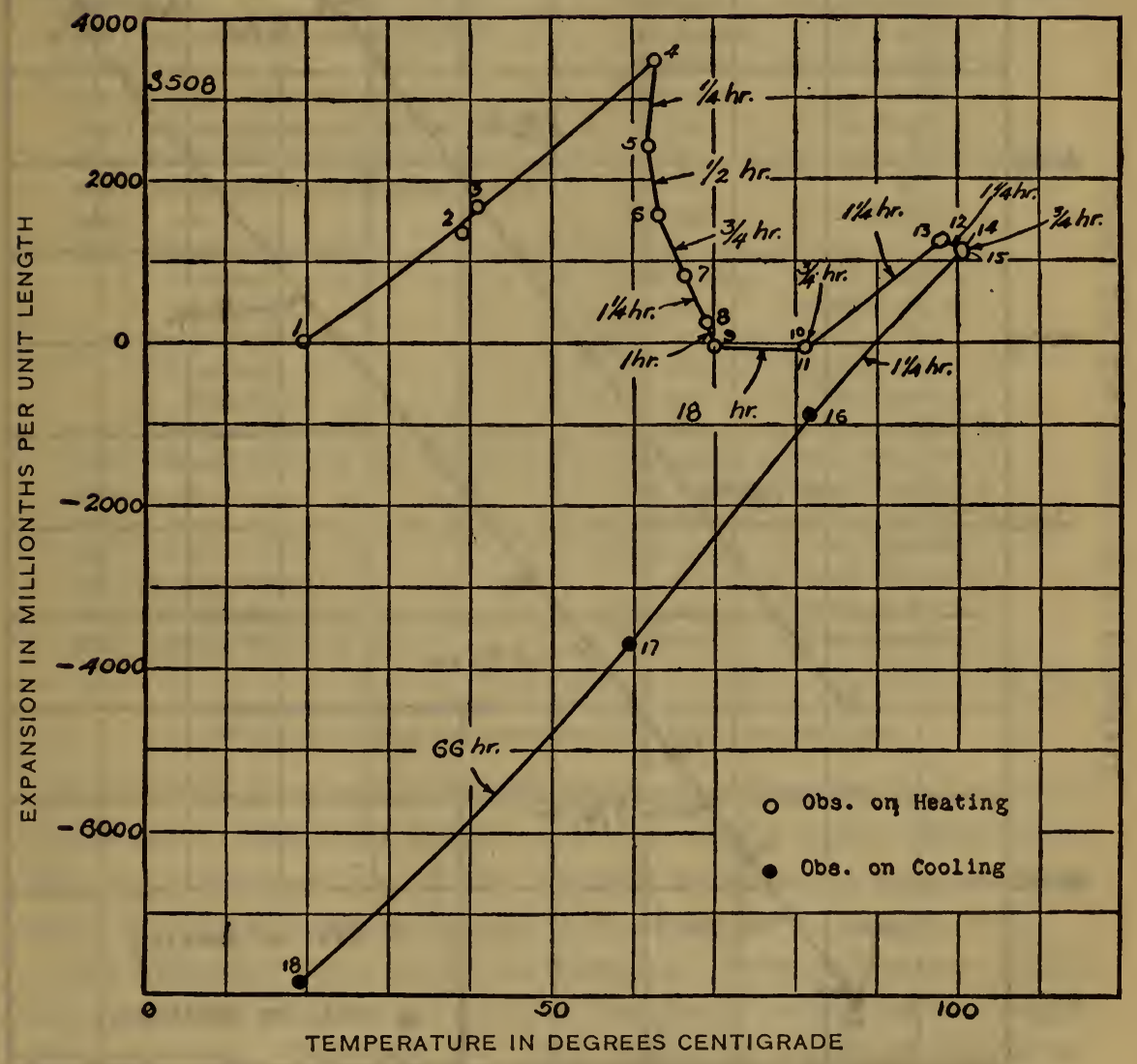

FIG. 18.-Expansion of hard rubber (S 508) 


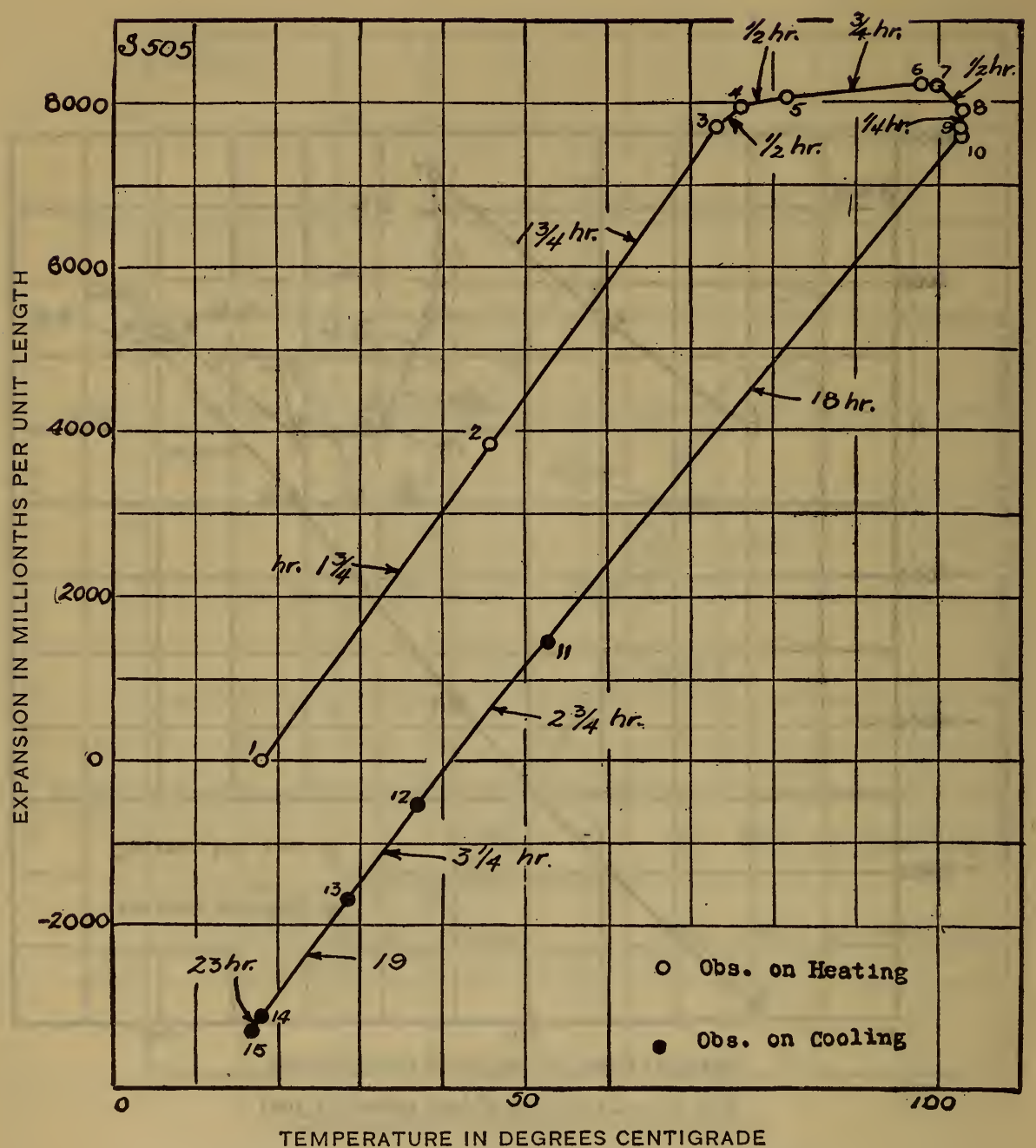

FIG. I9.-Expansion of celluloid (S 505) second heating 
The coefficients of expansion obtained on various samples of these materials are summarized in the following table:

TABLE 4

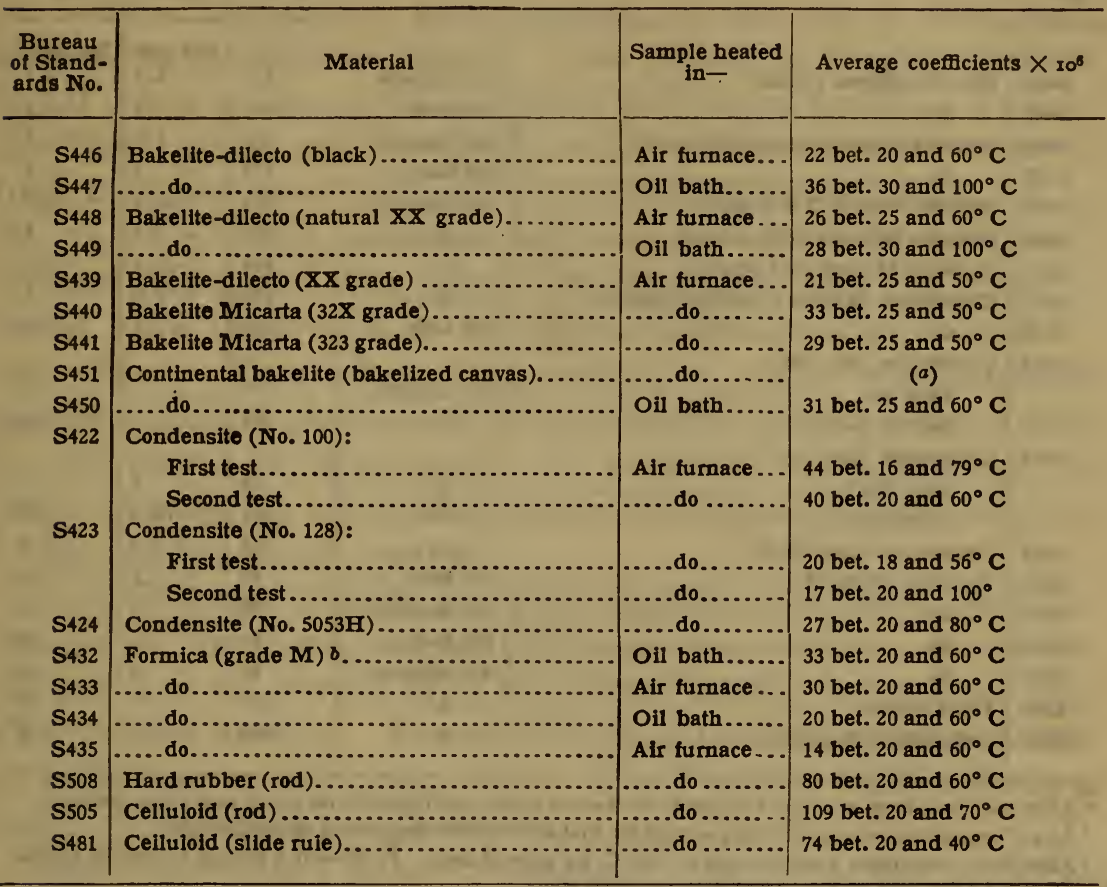

a Expansion very irregular.

$b$ Nos. $S_{432}$ and $S_{433}$ were cut perpendicular to Nos. $S_{434}$ and $S_{435}$.

Most of these materials when kept at some constant temperature above $60^{\circ} \mathrm{C}$ shrink in length and lose weight (give off vapors). When the temperature of the material increases it expands, but when kept at a constant temperature above $60^{\circ} \mathrm{C}$ it contracts.

The following table gives the maximum temperatures to which the specimens were heated and the changes in weight and in length after the test. The plus $(+)$ sign indicates a gain in weight or length and the minus (-) sign a diminution in weight or length 
TABLE 5

\begin{tabular}{|c|c|c|c|c|c|}
\hline $\begin{array}{l}\text { Bureau } \\
\text { of Stand- } \\
\text { dards } \\
\text { No. }\end{array}$ & Material & $\begin{array}{l}\text { Sample heated } \\
\text { in- }\end{array}$ & $\begin{array}{c}\text { Maxi- } \\
\text { mum } \\
\text { tempera- } \\
\text { ture }\end{array}$ & $\begin{array}{c}\text { Change } \\
\text { in weight } \\
\text { after } \\
\text { test }\end{array}$ & $\begin{array}{c}\text { Change } \\
\text { in length } \\
\text { after } \\
\text { test }\end{array}$ \\
\hline S446 & Bakelite-dilecto (black)... & Air furnace... & ${ }^{\circ} \mathbf{C}_{172}$ & $\begin{array}{r}\text { Per cent } \\
-6.3\end{array}$ & $\begin{array}{r}\text { Per cent } \\
-0.4\end{array}$ \\
\hline S447 & .....do............................. & Oil bath...... & 147 & -.1 & -.2 \\
\hline S448 & Bakelite-dilecto (natural XX grade). & Air furnace. & 191 & -2.8 & -.2 \\
\hline S449 & .....do.............................. & Oil bath.... & 175 & -.3 & -.2 \\
\hline $\mathbf{S 4 3 9}$ & Bakelite-dilecto (XX grade) $a \ldots$ & Air furnace. & 253 & -20.4 & -1.5 \\
\hline $\mathbf{S} 440$ & Bakelite Micarta ( $32 \mathrm{X}$ grade).... & ..... do ...... & 195 & -2.7 & -.4 \\
\hline S441 & Bakelite Micarta ( 323 grade) a......... & ..... do ....... & 246 & -27.6 & -4.0 \\
\hline S451 & Continental bakelite (bakelized canvas). & .... do ....... & 170 & -2.0 & -.1 \\
\hline S450 & .....do & Oil bath.... & 160 & +.1 & -.2 \\
\hline \multirow[t]{3}{*}{ S422 } & Condensite (No. 100): & & & & \\
\hline & First test $\ldots \ldots \ldots \ldots$ & Air furnace. & 79 & $\cdots$ & -.2 \\
\hline & Second test $b . . . \ldots \ldots$ & ......do... & 288 & 0 & -4.3 \\
\hline \multirow[t]{3}{*}{ S423 } & Condensite (No. 128): & & & & \\
\hline & First test $c \ldots \ldots \ldots$. & ..... do ....... & 94 & -.5 & -.1 \\
\hline & Second test............... & ..... do ....... & 304 & -4.0 & -.6 \\
\hline S424 & Condensite (No. 5053H) ..... & ..... do ....... & 124 & -2.3 & -.3 \\
\hline S432 & Formica (grade $\mathbf{M}) \ldots \ldots \ldots$ & Oil bath....... & 60 & +.2 & -.01 \\
\hline S433 & .....do................. & Air furnace ... & 79 & -.6 & -.14 \\
\hline S434 & ....do................ & Oil bath ....... & 61 & +.2 & .00 \\
\hline S435 & .....do............... & Air furnace... & 66 & -.3 & -.03 \\
\hline S508 & Hard rubber.......................... & ...... do .......... & 100 & -.1 & -.8 \\
\hline S505 & Celluloid ( 2 heatings)........... & $\ldots .$. do .......... & 103 & -1.1 & -1.4 \\
\hline
\end{tabular}

$a$ After test, specimen was found warped, cracked on sides, and blistered on upper and lower surfaces.

b At $288^{\circ}$, specimen was contracting so rapidly that one end left support of the apparatus.

c After test $\mathrm{r}$, specimen kept in oven at $100^{\circ} \mathrm{C}$. for several days. It showed a change in weight and in length of -0.6 per cent and -0.1 per cent, respectively.

From a study of the work on these materials it is evident that the length is a function of the temperature, medium in which the material is heated (air or oil), time, rapidity of heating or cooling, etc

From these experiments the conclusion may be drawn that delicate apparatus made from these materials or containing these materials as essential parts should not be heated above $60^{\circ} \mathrm{C}$ $\left(140^{\circ} \mathrm{F}\right)$, if loss in weight and shrinkage or warpage are to be avoided.

The Bureau takes this opportunity of thanking the manufacturers of the above products for their cooperation in this research. Practically all of the above samples were given the Bureau by the respective manufacturers. 


\section{MARBLE AND LIMESTONE}

This research ${ }^{12}$ includes ro grades of marble ${ }^{13}$ selected from the quarries of Vermont, Tennessee, and Georgia, and one specimen of Indiana limestone. After heating, it was found that each showed an increase in length. This growth is roughly proportional to the maximum temperature, as is shown by $\mathrm{S} 209$ (Florentine blue), which was heated to $100^{\circ} \mathrm{C}$, cooled to room temperature, then heated to $150^{\circ}$, and cooled to room temperature, and so on. Each cycle of increased temperature caused an additional increase in length. The dotted line represents how the material would have behaved if it had been heated directly to $300^{\circ} \mathrm{C}$. (See S207.) Then after being cooled, it would have returned approximately to point II, which represents a growth of more than 0.3 per cent. In other words, the growth is approximately the same, whether the specimen is heated by cycles or heated directly to the maximum temperature.

Si 98 (Pittsford Italian) and S285 (Appalachian gray) show the changes in length on two heatings and two coolings. It will be noticed that the growth after the second heating is less than that after the first heating. Repeated heatings tend to bring the marble to a constant or permanent state. The Vermont marble shows a larger growth than the Tennessee.

S296 (Silver gray) shows the changes in length at low temperatures. On cooling below room temperature, it is seen that the specimen expands, contrary to the usual behavior of most materials. The coefficient of expansion of this specimen on the first cooling was numerically (but opposite in sign) about the same as that of steel at room temperature. For the other marbles tested, however, the coefficients of expansion on cooling are quite small, as may be seen from Table 7 . The peculiar phenomenon of minimum length is common to all the specimens tested. This point of minimum length is not constant for the different kinds of marble, and usually occurs below room temperature, in some instances as low as $-20^{\circ} \mathrm{C}$. Attention is directed to the slight permanent lengthening of specimens when passed through the cooling cycle.

12 Parts of these data on marble were taken under the direction of $\mathrm{L}$. W. Schad, formerly of this Bureau.

${ }^{2}$ Selected by D. W. Kessler, of this Bureau. For additional physical and chemical properties see Bureau of Standards Technologic Paper No. r23. 


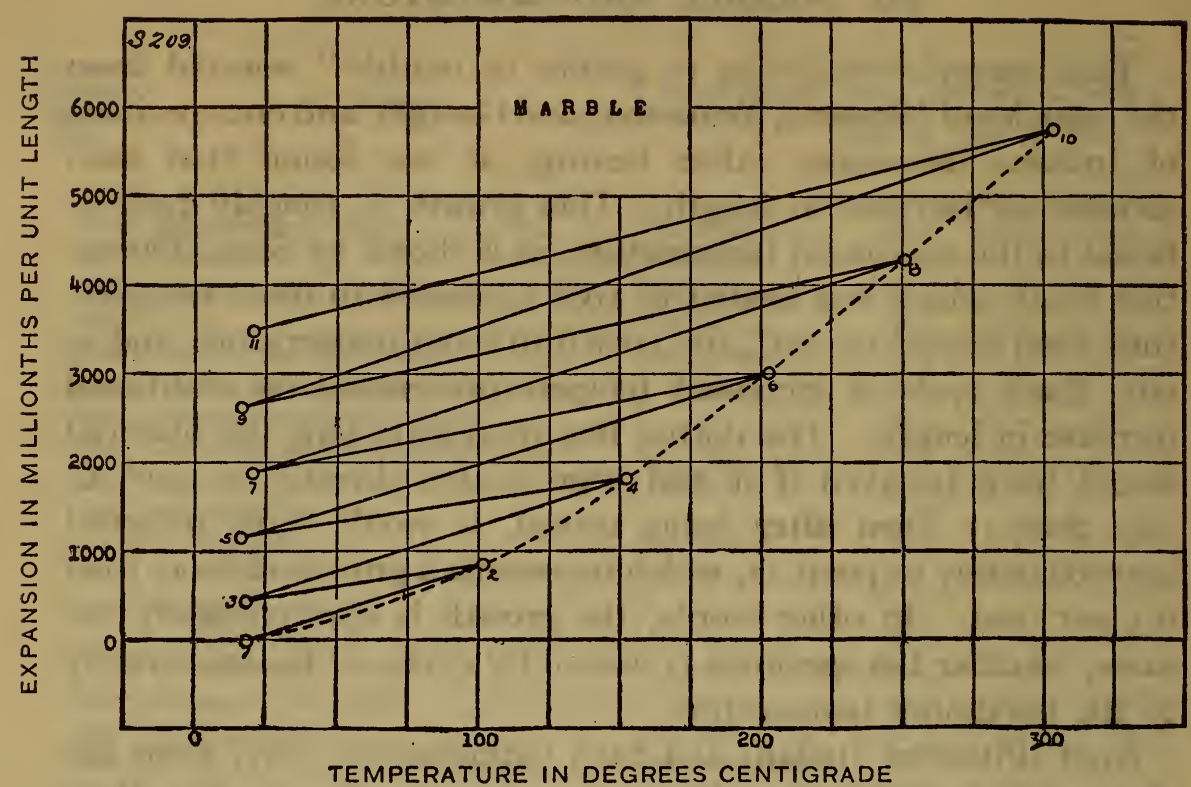

FIG. 20.-Expansion and growth of marble (S 209)

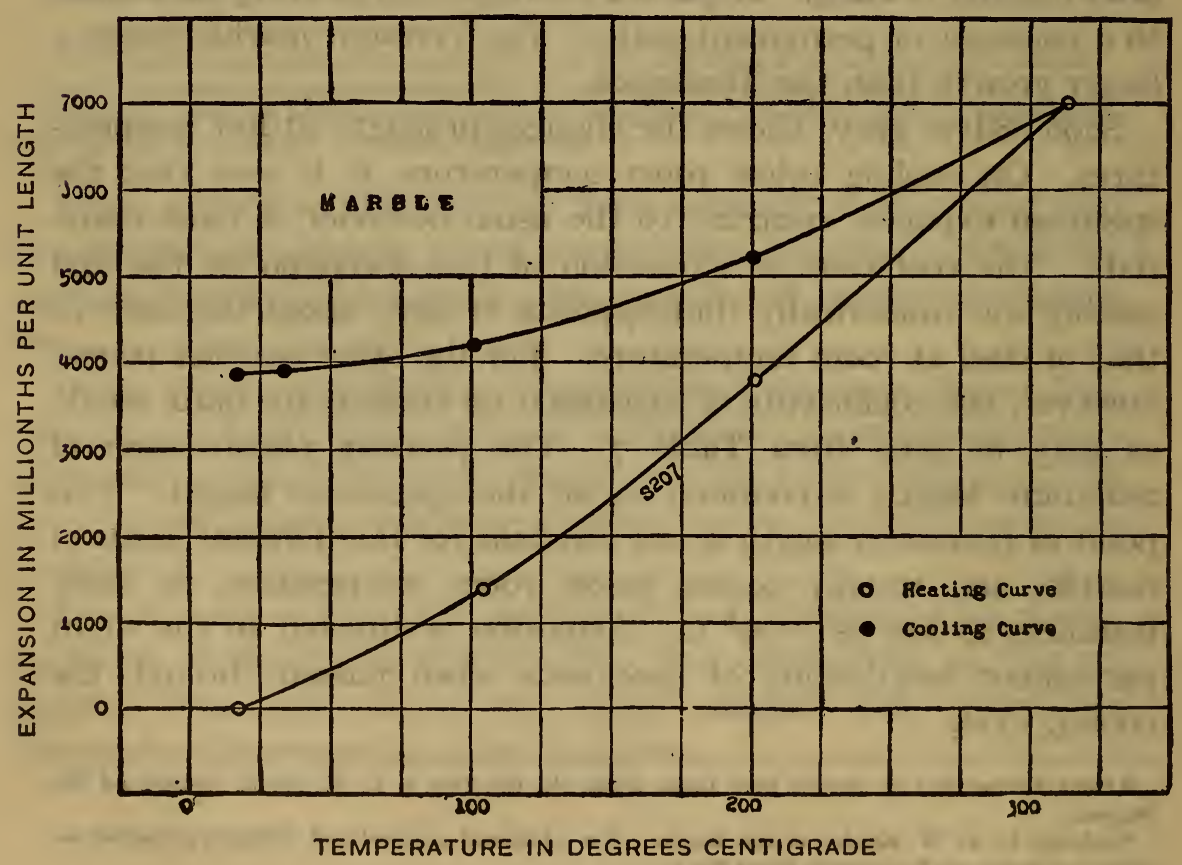

FIG. 21.-Expansion of marble. (S 207) 


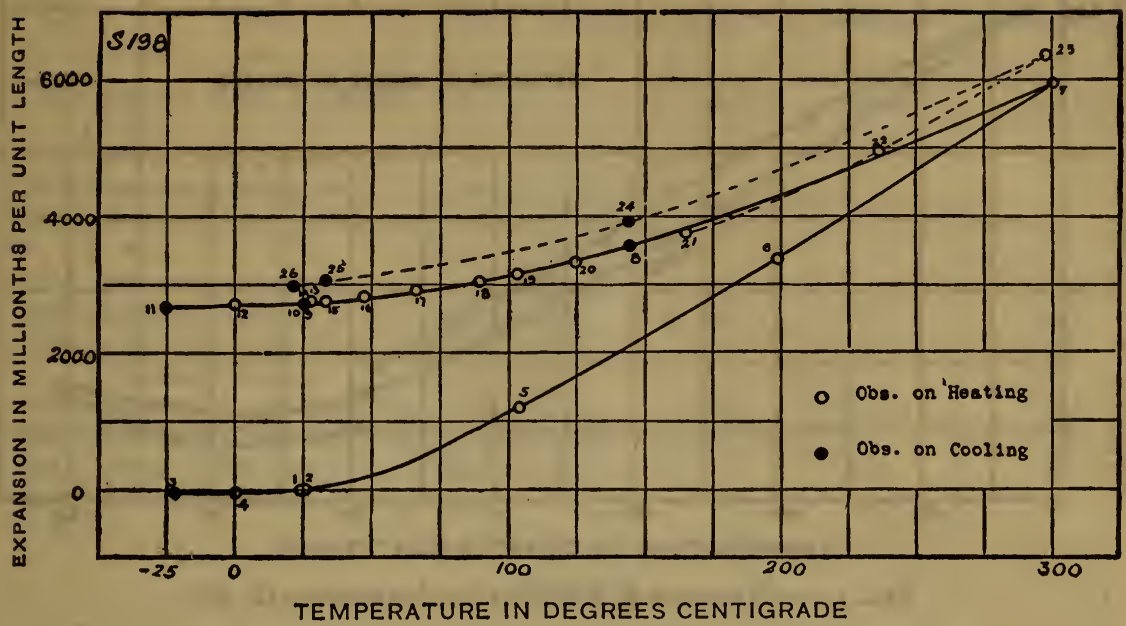

FIG. 22.-Expansion of marble (S Ig8)

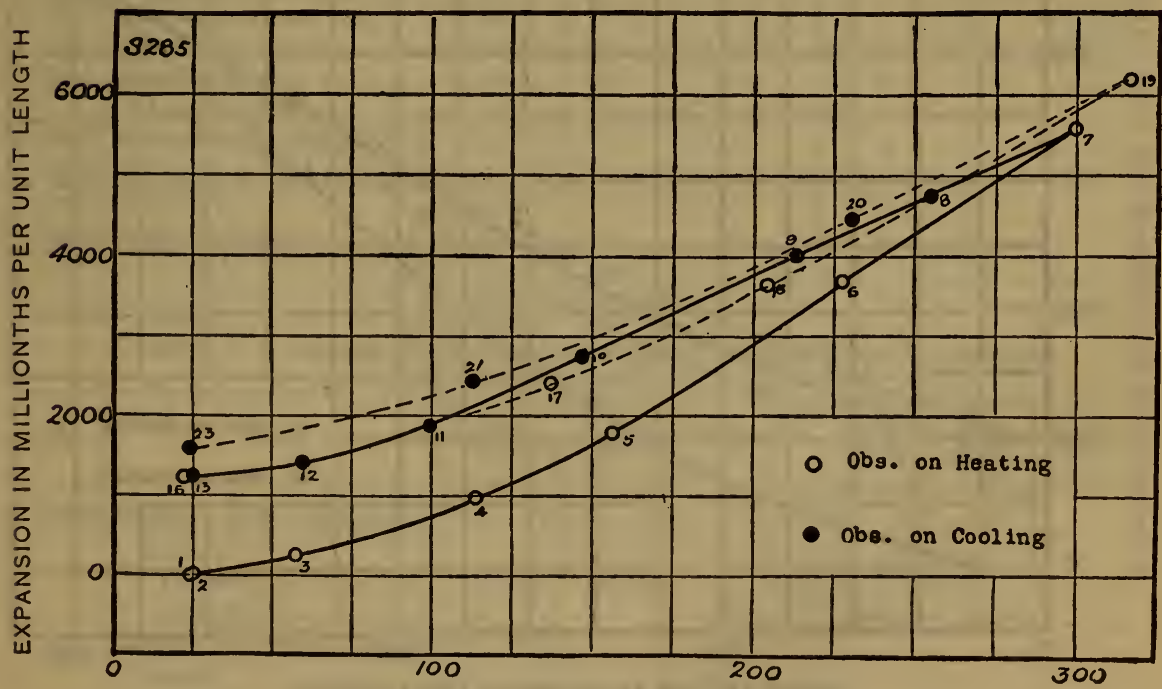

TEMPERATURE IN DEGREES CENTIGRADE

Fig. 23.-Expansion of marble ( $S$ 285) 


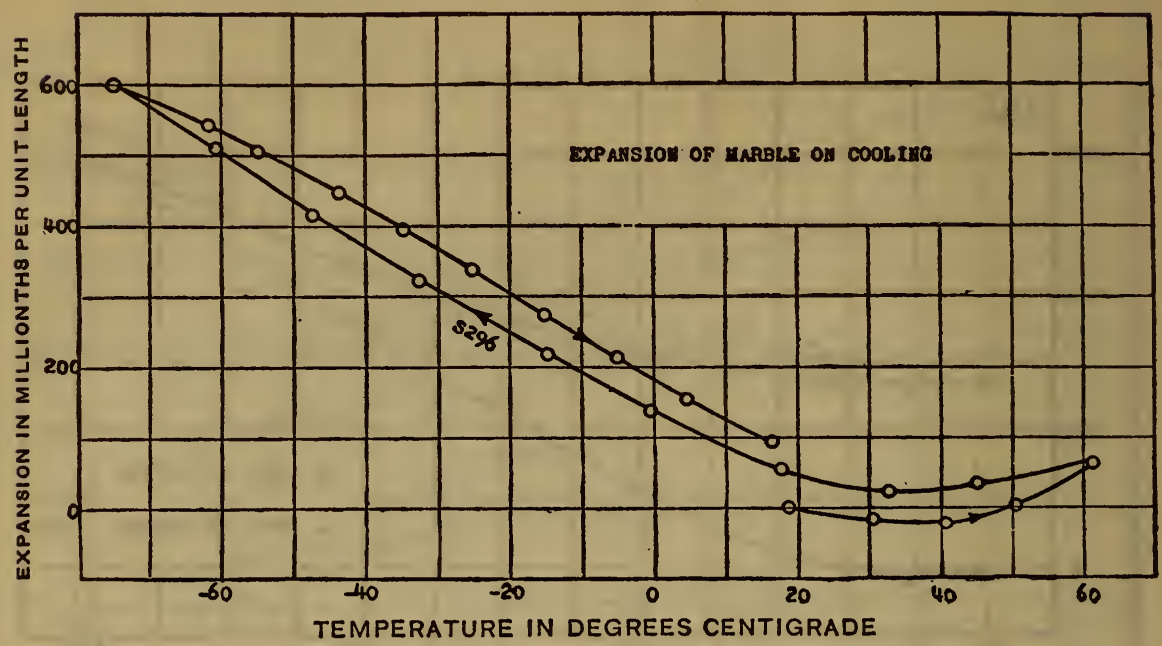

FIG. 24.-Expansion of marble at low temperature ( $S$ 296)

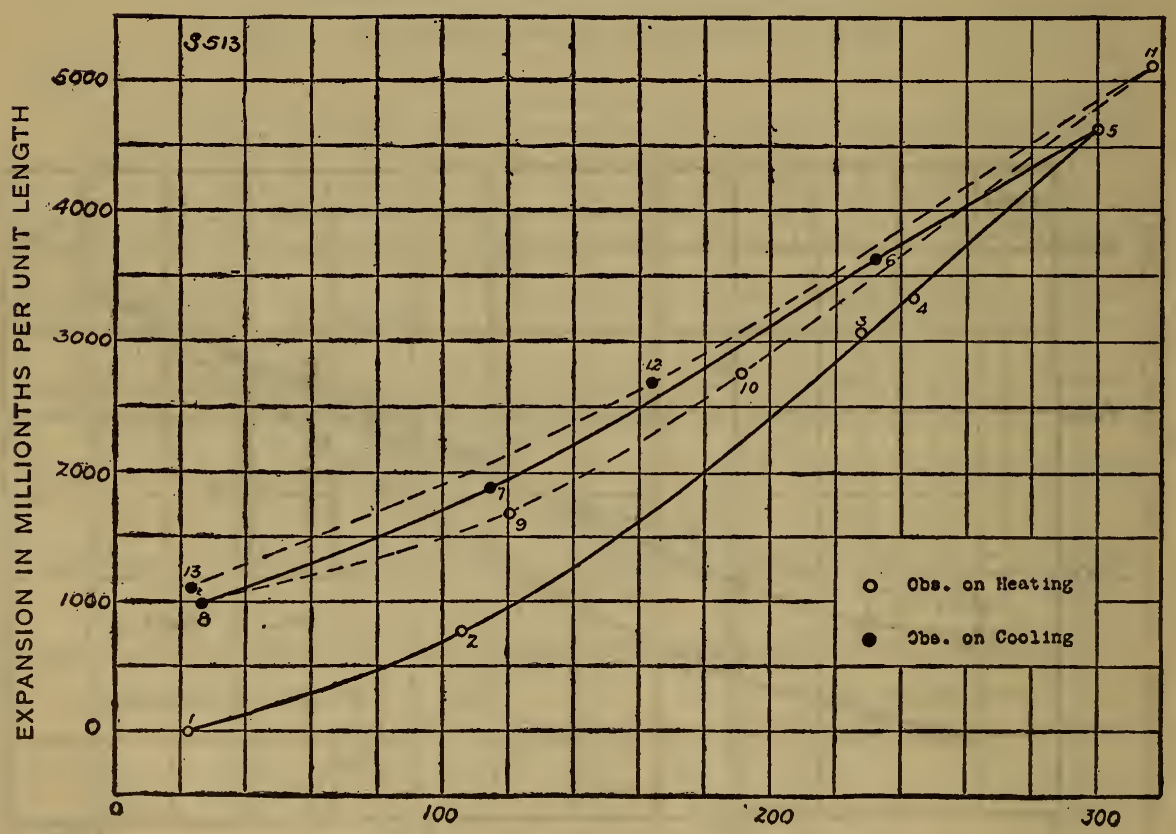

TEMPERATURE IN DEGREES CENTIGRADE

FrG. 25.-Expansion of limestone ( $\left.S_{513}\right)$ 
TABLE 6.-Average Coefficients Above Room Temperature HEATING

\begin{tabular}{|c|c|c|c|c|c|c|}
\hline$\underset{\text { ber }}{\text { Num- }}$ & Name & $\begin{array}{l}\text { Heated } \\
\text { in- }\end{array}$ & 20 to $65^{\circ} \mathrm{C}$ & 25 to $100^{\circ} \mathrm{C}$ & 100 to $200^{\circ} \mathrm{C}$ & 200 to $300^{\circ} \mathrm{C}$ \\
\hline S198 & $\begin{array}{l}\text { Pittsford Italian, } \perp \text { (Pittsford, } \\
\text { Vt.) }\end{array}$ & Oll... & $\ldots \ldots \ldots \ldots$ & $14 \times 10^{-6}$ & $23 \times 10^{-6}$ & $25 \times 10^{-6}$ \\
\hline $\mathbf{S 2 0 7}$ & Rutland blue, $\perp$ (Rutland, Vt.). & ...do..... & .............. & 16 & 25 & 29 \\
\hline $\mathbf{S} 208$ & Dorset gray (Dorset, Vt.)....... & ...do..... & $10 \times 10^{-6}$ & - $\ldots$ & & \\
\hline $\mathbf{S 2 0 9}$ & $\begin{array}{l}\text { Florentine blue, } \perp \text { (Plorence, } \\
\text { Vt.). }\end{array}$ & ...do.... & (........... & 10 & - & . \\
\hline $\mathbf{S} 210$ & Riverside, $\perp$ (Proctor, Vt.) ..... & ...do.... & ............. & 13 & ............. & 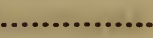 \\
\hline $\mathbf{S 2 8 5}$ & Appalachian gray, $1 \ldots . . . . .$. & Air...... & & 10 & 22 & 27 \\
\hline $\mathbf{S 2 8 6}$ & $\begin{array}{l}\text { Appalachian gray, } 1 \ldots \ldots \ldots \ldots \\
\text { (Asbury, Tenn.). }\end{array}$ & ...do.... & ( $\ldots \ldots \ldots \ldots$ & 10 & 20 & 27 \\
\hline $\mathbf{S} 310$ & Rutland blue, $\perp$ (Rutland, Vt.)... & ...do.... & .............. & 15 & 23 & 28 \\
\hline $\mathbf{S} 296$ & Silver gray, $\|$ (Tate, Ga.)....... & .......... & $a 1$ & $\ldots \ldots$ & & \\
\hline S514 & Hollister $\|$ (Florence, Vt.)...... & Air...... & & 5 & 13 & 15 \\
\hline S513 & Indiana limestone............... & ...do.... & & 9 & 17 & 22 \\
\hline
\end{tabular}

COOLING

\begin{tabular}{|c|c|c|c|c|c|c|}
\hline $\begin{array}{l}\text { Num- } \\
\text { ber. }\end{array}$ & Name & $\underset{\text { in- }}{\text { Heated }}$ & 300 to $200^{\circ} \mathrm{C}$ & 200 to $100^{\circ} \mathrm{C}$ & 100 to $25^{\circ} \mathrm{C}$ & 65 to $20^{\circ} \mathrm{C}$ \\
\hline S198 & $\begin{array}{l}\text { Pittsford Italian, } \perp \text { (Pittsford, } \\
\text { Vt.). }\end{array}$ & Oil.... & $17 \times 10^{-6}$ & $11 \times 10^{-6}$ & $6 \times 10^{-6}$ & ............ \\
\hline $\mathrm{S} 207$ & Rutland blue, $\perp$ (Rutland, Vt.)... & ...do.... & 16 & 10 & 4 & ............. \\
\hline S208 & Dorset gray (Dorset, Vt.)....... & ...do.... & ............. & $\ldots .$. & $\ldots \ldots \ldots \ldots \ldots$ & $7 \times 10^{-6}$ \\
\hline $\mathrm{S} 285$ & Appalachian gray, $1 \ldots \ldots \ldots \ldots$ & Air...... & 19 & 18 & 9 & $\ldots \ldots \ldots \ldots \ldots$ \\
\hline $\mathbf{S} 286$ & $\begin{array}{l}\text { Appalachian gray, } \| \ldots \ldots \ldots \ldots . \\
\text { (Asbury, Tenn.) }\end{array}$ & ...do.... & 18 & 17 & 10 & .......... \\
\hline $\mathbf{S 3 1 0}$ & Rutland blue, $\perp$ (Rutland, Vt.)... & ...do.... & 15 & 9 & 4 & \\
\hline $\mathbf{S 2 9 6}$ & Silver gray, (Tate, Ga.)....... & & & & a. & $a 0.5$ \\
\hline S514 & Vermont, $\| . \ldots \ldots \ldots \ldots \ldots \ldots . . . .$. & Air...... & 7 & 3 & 0 & -. \\
\hline $\mathbf{S} 513$ & Indiana limestone............... & ...do.... & 15 & 14 & 10 & $\ldots \ldots \ldots \ldots$ \\
\hline
\end{tabular}

a After cooling test.

TABLE 7.-Average Coefficients on Cooling Below Room Temperature

\begin{tabular}{|c|c|c|c|c|c|c|c|}
\hline No. & Name & $\begin{array}{l}25 \text { to } \\
0^{\circ} \mathrm{C}\end{array}$ & $\begin{array}{c}0 \text { to } \\
-20^{\circ} \mathrm{C}\end{array}$ & -20 to $-40^{\circ}$ & $\begin{array}{l}-40 \text { to } \\
-60^{\circ} \mathrm{C}\end{array}$ & $\begin{array}{l}-60 \text { to } \\
-80^{\circ} \mathrm{C}\end{array}$ & $\begin{array}{l}-80 \text { to } \\
-95^{\circ} \mathrm{C}\end{array}$ \\
\hline \multirow[t]{3}{*}{ S283 } & $\begin{array}{l}\text { Victoria pink } \perp \text { (Knorville, } \\
\text { Tenn.): }\end{array}$ & & & & & & \\
\hline & First test.................. & $4 \times 10^{-6}$ & $1 \times 10^{-6}$ & & & & \\
\hline & Second test.............. & 3 & 1 & $-4 \times 10^{-6}$ & $-4 \times 10^{-6}$ & $-2 \times 10^{-6}$ & \\
\hline \multirow[t]{3}{*}{ S287 } & $\begin{array}{l}\text { Cumberland pink } \perp \text { (Meadow, } \\
\text { Tenn.): }\end{array}$ & & & & & & \\
\hline & First test.................. & 4 & 1 & -3 & -3 & -2 & $-1 \times 10^{-6}$ \\
\hline & Second test................ & 2 & 0 & -2 & -2 & ..... & .......... \\
\hline \multirow[t]{3}{*}{ S296 } & Silver gray, I (Tate, Ga.): & & & & & & \\
\hline & First test................... & -13 & -10 & -10 & -10 & -12 & $\cdots$ \\
\hline & Second test................. & -4 & -6 & -6 & -7 & & \\
\hline
\end{tabular}


Tables 6 and 7 give the coefficients of expansion of the various samples. The former table gives the values on the first heating; and the latter, on cooling below room temperature. The coefficients are higher on the first heating than on any subsequent heating. The symbols $\perp$ and $\|$ are used in the table to indicate the direction of the grain, the former representing specimens cut perpendicular to the bed and the latter parallel to the bed. Little, if any, difference in expansion can be detected; e. g., $\mathrm{S}_{2} 85$ and $\mathrm{S} 286$ are from the same block of marble, but cut in opposite directions to the grain.

The following table gives the principal constituents of the marbles investigated:

TABLE 8.-Chemical Analysis

\begin{tabular}{|c|c|c|c|c|c|c|c|}
\hline Number $a$ & $\mathrm{CaO}$ & $\mathrm{CO}_{2}$ & $\mathrm{MgO}$ & $\mathrm{Al}_{2} \mathrm{O}_{3}$ & $\mathrm{Fe}_{2} \mathrm{O}_{3}$ & $\begin{array}{l}\text { Loss on } \\
\text { Ignition }\end{array}$ & $\begin{array}{l}\text { Insoluble } \\
\text { in } \mathbf{H C l}\end{array}$ \\
\hline S198... & 54.49 & 43.65 & 1.33 & 0.20 & 0.05 & 43.81 & 0.4 \\
\hline s207... & 55.90 & 43.80 & .27 & .06 & .02 & 43.90 & .34 \\
\hline s208... & 55.40 & 43.46 & .35 & .06 & .04 & 43.78 & .70 \\
\hline S209.... & 55.60 & 43. 94 & .44 & .07 & .01 & 43.86 & .31 \\
\hline S210 b.. & 55.40 & 43.76 & .35 & .10 & .01 & 43.70 & .2 \\
\hline s285... & 55.60 & 43.58 & .07 & .26 & .06 & 43.89 & .15 \\
\hline S286.... & 55.60 & 43.58 & .07 & .26 & .06 & 43. 89 & .15 \\
\hline S310.... & 55.90 & 43.80 & .27 & .06 & .02 & 43.90 & .34 \\
\hline S296.... & 55.00 & 43.18 & .41 & .09 & .04 & 43.37 & 1.10 \\
\hline S514... & 55.54 & 43.75 & .46 & .09 & .03 & 43.81 & .24 \\
\hline S283..... & 55.38 & 43.52 & Trace & .14 & .06 & 43.95 & .08 \\
\hline S287....... & 55.80 & 42.65 & .06 & .45 & .16 & 43.68 & .5 \\
\hline
\end{tabular}

The difference in the coefficients of the various marbles when compared with each other or the difference of some marbles when compared with certain metals, raises a question of the advisability of assembling these in structures, subject to large temperature variations, where close or accurate relative dimensions are to be maintained unless proper compensating facilities are provided.

Length measurements made two years after these tests indicate that the growth of marble after heating is permanent.

\section{SUMMARY}

The present paper gives data on the thermal expansion of some of the more important insulating materials.

A short description of the method employed in making the observations is given. A photograph of one of the furnaces and the microscopes is shown in Fig. $\mathrm{I}$. 
The dimensional changes incident to temperature variations have been measured. In most cases the expansions are too irregular to justify the use of the general quadratic equations.

The coefficients of 40 samples of various kinds of porcelain were found to vary over a wide range, from r.6 to 19.6 millionths per unit length per degree centigrade. The coefficients of expansion are given in Table 2. The expansion curves of most materials are concave; but with porcelain three kinds of curves were found, namely, straight-line, concave, and convex curves. No marked set or permanent change in dimension due to the heat treatment was observed. Porcelains having low coefficients exhibited marked resistance to sudden temperature changes.

To understand the work done on the phenol condensation products (bakelite, condensite, formica, etc.), it is necessary to refer to the representative figures. (See p. 399.) The most striking peculiarity is the shrinkage and the loss in weight of most of these materials when subjected to temperatures above $60^{\circ} \mathrm{C}$. A summary of the values obtained is given in Tables 4 and 5 .

Marble and limestone showed a permanent growth when subjected to heat treatment. On cooling below room temperature, it was found that marble has a negative coefficient of expansion. The coefficients of expansion are given in Tables 6 and 7 .

A knowledge of the thermal behavior of these materials is essential before assembling them in certain types of apparatus subjected to wide temperature variations.

We are indebted to John O. Eisinger for assistance in computing, etc.

WASHINGTON, June 30, I9I9. 



$$
10
$$


